\title{
Experimental Studies on Exophthalmos in Hyperthyroidism
}

\author{
- Studies on Exophthalmos Producing Substance--
}

\section{Hiromasa TORIBE}

The 1st Department of Internal Medicine, Osaka City University, Medical School

\author{
(Director : Professor Kenzo Shiota)
}

In order to obtain some information about endocrine exophthalmos, the author attempted to determine the exophthalmos producing activity of desiccated thyroid (thyradine), thyroxine $\left(\mathrm{T}_{4}\right)$ and triiodothyronine $\left(\mathrm{T}_{3}\right)$, to separate exopthalmos producing substance (EPS) from thyroid stimulating hormone (TSH) with column chromatography using pig thyrotropin preparation (pretiron) as the starting material and finally to test the effect of the thyroid hormone preparations on the exophthalmos producing response in gold fish, induced by pretiron.

The bioassay of EPS was performed by the determination of the percent increase in intercorneal distance (ICD) in gold fish after the intracloacal injection of the materials. The bioassay of TSH was performed with Bakke-Ogura's in vitro method using the suppressive effect of TSH on the release of ${ }^{131} \mathrm{I}$ from bovine thyroid slice. Column chromatography was performed on CM-G and DEAE-C.

The following results were obtained:

1) No marked diurnal variation was observed in ICD in gold fish, and ICD was not affected by the operative procedure of cutting off the fins or intracloacal puncture.

2) As the increase in ICD after the injection of $0.9 \%$ saline was under $5 \%$, the author defined that an increase over $5 \%$ was significant. Macroscopic exophthalmos was observed at $3 \mathrm{hrs}$. after the injection of 5 Junkmann-Schoeller Units (JSU) of pretiron, and the peak of percent increase was reached at about 5 hrs.. The exophthalmic response of gold fish was decreased in summer when water temperature showed above $30^{\circ} \mathrm{C}$.

3) At $5 \mathrm{hrs}$. after the injection of pretiron a linear responsiveness of percent increase in ICD to graded doses of TSH was observed to be between 1.25 JSU and 10.0 JSU of pretiron, but on the other hand, at $10 \mathrm{hrs}$ it was observed to be between $1.25 \mathrm{JSU}$ and 5.0 JSU.

4) Chromatographing pretiron on CM-G using $0.01 \mathrm{M}$ phosphate buffer solution for the first elution, and $1.0 \mathrm{M} \mathrm{NaCl}$ for the second, the second fraction had biologically highly thyroid stimulating and exophthalmos producing activity. Changing the elute beffer gradiently from the phosphate buffer to $1.0 \mathrm{M} \mathrm{NaCl}$, the latter half of the second fraction also showed both thyroid stimulating and exophthalmos producing activity.

5) DEAE-C, 0.005 M glycine-NaOH, 0.1 M glycine-NaOH, $0.2 \mathrm{M} \mathrm{NaH}_{2} \mathrm{PO}_{4}$ and 1.0 $\mathrm{M} \mathrm{NaCl}$ were used as the elute buffer. The fractions eluted by the 1st, 2nd, 3rd and 
4th buffer were named Fraction I, II, III and IV, respectively. Fraction III showed marked thyroid stimulating activity, and Fraction II, III and IV showed exophthalmos producing activity equally.

6) An exophthalmic response was observed on the 4th day following the administration of a large quantity $(20 \mathrm{mg}$ ) of thyradine, but it was not observed following the administration of $\mathrm{T}_{3}$ or $\mathrm{T}_{4}$.

7) The pretreatment with $T_{3}$ showed a marked, inhibiting effect on exophthalmos production by pretiron, compared with that of thyradine or $\mathrm{T}_{4}$.

From the results above mentioned, it is suggested that EPS is distinct from TSH and that $\mathrm{T}_{3}$ may be used as one of the therapeutic drugs for proptosis in patients with hyperthyroidism. 


\title{
甲状腺機能穴進症における眼球突出に関する実験
}

\author{
眼球突出因子に関する実験 \\ 大阪市立大学医学部第一内科教室 （主任 塩田憲三教授） \\ 鳥 邊 博 正
}

(昭和 39 年 7 月 16 日受付)

\section{I 緒 言}

甲状腺機能穴進症は内分泌性疾患の中では糖尿病と共に最も多い疾患である.甲状腺機能克進症には眼球 突出（以下眼突と略す）を伴う場合（Basedow 氏病）と，伴わない場合（不全型）とがあり，ての眼突の 病態生理を解明するために種々の試みがなされてきた。

1931年 Schockaert ${ }^{1)}$ はアヒルに下垂体抽出物を注射して初めて実験的に眼突を起てしており，その後 Albert ${ }^{2}$ (1945年) が下垂体抽出物に非常に感受性のある common Atlantic “minnow”(killifish =Fundulus heteroclitus Linn.) をみつけてから，其の後多くの研究者により種々の魚を用いて前葉抽出物や TSH 製 剤に眼球突出惹起活性 (Exophthalmos producing activity) のあるととがほぼ確認されている. 1953年 Dobyns and Steelmann ${ }^{3)}$ は前葉抽出物に $8 \%$ 三塩化酢酸を加えて，TSH 作用はないが眼突効果の著明な物 質を分離してれを Exophthalmos producing substance（以下 EPS と略す）と呼んだ。 Jefferies' ${ }^{4)}$ (1949 年) は前葉抽出物を沃度化するととにより，又 Brunish ${ }^{5)}$ (1958年) はてれを pepsin で消化するととにより TSH 作用はなくなるが眼突作用は残しることから両者は別個のものであると考帛た。

そこで著者は Condliffe and Bates ${ }^{6,7}$ ，Condliffe et al ${ }^{8)}$ 等が粗製 TSH から TSH を精製している cellulose column chromatography を応用して, TSH と EPS が chromatographic に別個の行動をと るのではないかと考え，TSH 製剤であるPretiron を用いて両者の分離を試みんとした。

一方 Langford ${ }^{9}$ (1957年) や Matty et $\mathrm{al}^{10)}$ (1958年) 等は乾燥甲状腺末, Thyroxine $\left(\mathrm{T}_{4}\right)$, Triiodothyronine $\left(T_{3}\right)$ の甲状腺ホルモンで眼突が起きたとしているが，Albert ${ }^{2)}$ (1945年)，Day ${ }^{11)}$ (1960年)，Dobyns et $\mathrm{al}^{12)}$ (1962年）等は又てれと反対の報告をしており一定していない. 著者はてれら甲状腺ホルモンの眼突 惹起活性の有無を, 大量投与の場合と少量投与の場合とで比較検討すると同時に，甲状腺ホルモンの前投与 が Pretiron の眼突苾起活性に如何なる影響を与えるかにつき検討を加えた。

\section{II 実験材料並びに実験方法}

\section{1. 試薬並びに材料}

$\mathrm{NaH}_{2} \mathrm{PO}_{4} \cdot 2 \mathrm{H}_{2} \mathrm{O}$

$\mathrm{Na}_{2} \mathrm{HPO}_{4}$

$\mathrm{NaCl}$

Glycocoll $\left(\mathrm{NH}_{2} \mathrm{CH}_{2} \mathrm{COOH}\right)$

$\mathrm{NaOH}$

以上和光純薬の試薬特級を使用.

Carboxymethyl-Cellulose (GM-G) - Brown，イオン交換容量 $0.8 \mathrm{mEq} / \mathrm{gm}$

Dietbylaminoethyl-Cellulose (DEAE-C) - Brown, イオン交換容量 $0.9 \mathrm{mEq} / \mathrm{gm}$

以上 Pharmacia Uppsala Sweden のものを使用. 
2. 試料

Pretiron (Schering 社製品)

1アンプル中に500モルモット単位（Ms. E.=Junkmann-Schoeller Units）を含有する TSH 製剤で, 豚 の下垂体前葉より特殊の抽出法で得られたもの. 下垂体後葉ホルモン，卵胞刺㦸ホルモン，プロラクチン， 副腎皮質刺㦸ホルモン等を含まない。

Thyradine（帝国藏器製品）

発育完全な健康哺乳動物の新鮮な甲状腺より特殊の抽出法で得られた甲状腺ホルモン製剤で，1 $\mathrm{ml}$ 中に 日本薬局方乾燥甲状腺 $0.2 \mathrm{gm}$ 相当を含有.

Thyroxine (The Britisch Drug Houses LTD. 製品)

L-Thyroxine Sodium Salt として存在.

Thyronamine（武田薬品製品）

L-3, 5, 3'-Triiodothyronine Sodium Salt として存在.

\section{Cellulose Column の調製}

Condliffe, Bates and Fraps ${ }^{8)}$ の報告に従い GM-C, DEAE-C 約 $20 \mathrm{gm}$ に夫々 $0.5 \mathrm{~N} \mathrm{NaOH}$ と $\mathrm{NaCl}$ の 混合液を加えて良く㩭拌し，吸引鐘に入れて水流ポンプにて減圧し， cellulose に吸着せる空気を完全に除 去してから，先端に綿をつめた $2.5 \times 50 \mathrm{~cm}$ の column に充填し，更に同混合液で洗溁し，てれに約 $1 l$ を 使用した．次いで脱イオン水を滴加して流出液の $\mathrm{pH}$ が約6になる迄洗涤し，そして流出液を日立製 Spectrophotometer (type EPU-2A) を用いて波長 $276 \mathrm{~m} \mu$ にて吸收率を測り，吸光度が0.020 以下なる事を 確かめてから， CM-C には pH 6.3, 0.01M の phosphate buffer を，DEAE-C には pH 9.5, 0.005M の glycine- $\mathrm{NaOH}$ buffer を流し，流入液と流出液の $\mathrm{pH}$ が一致する迄 bufferize した後 cold room に保存 した. buffer の pH 值は日立製 $\mathrm{pH}$ Meter (Type EHP-2) を使用して測定した.

4. 試料の調製

Pretiron initial buffer 即ち GM-G では $0.01 \mathrm{M}$ phosphate buffer $2.0 \mathrm{ml}$; DEAE-G では $0.005 \mathrm{M}$ glycine- $\mathrm{NaOH}$ buffer $2.0 \mathrm{ml}$ で溶解し，その1.0ないし $1.5 \mathrm{ml}$ を cellulose column に添加し，ついで次 に述べる elute solvent そて展開溶出した.

\section{Column Chromatography の実施条件}

column size は $0.9 \times 20 \mathrm{~cm}$

fraction size $45 \mathrm{ml}$

temperature は $0^{\circ} \sim 4^{\circ} \mathrm{C}$ (cold room にて行なう)

elute volume は $18 \sim 21 \mathrm{ml} / \mathrm{hr}$.

solvent $は$

1) GM-C pH 6.3, 0.01M phosphate buffer のあとは

a) $1.0 \mathrm{M} \mathrm{NaCl}$ で stepwise 亿展開溶出

b) $1.0 \mathrm{M} \mathrm{NaCl}$ で gradient に展開溶出

の二方法を実施. Gradient elution は Alm et al ${ }^{13)}$ を参考にして行なつた. (Fig. 1)

2) DEAE-C $\mathrm{pH} 9.5,0.005 \mathrm{M}$ glycine- $\mathrm{NaOH}$ のあとは stepwise $飞 \mathrm{pH} 9.5,0.1 \mathrm{M}$ glycine- $\mathrm{NaOH}$ で, ついで $0.2 \mathrm{M} \mathrm{NaH} \mathrm{PO}_{4}, 1.0 \mathrm{M} \mathrm{NaCl}$ の順で展開溶出.

$5 \mathrm{ml}$ 宛 fraction collector で集めた各試験管の吸収率を $276 \mathrm{~m} \mu$ にて測定し, 吸収率の peak の部分を それぞれ pool して透析し，凍結乾燥して白色粉末を得，ての粉末にそれぞれ $0.9 \% \mathrm{NaCl} 2.0 \mathrm{ml}$ を加えて 溶解し，各々 TSH の bioassay と金魚眼突の bioassay に使用した。

\section{TSH 活性の Bioassay (Bakke-小倉氏法 ${ }^{14)}$ )}

in vitro 法で新鮮な牛甲状腺スライスに ${ }^{131} \mathrm{I}$ を含むヨードを負荷しておき，乙のスライスを各段階に稀 釈した TSH を含む標準液中で incubate すると， medium 中に放出されるヨードの量はTSH によつて 


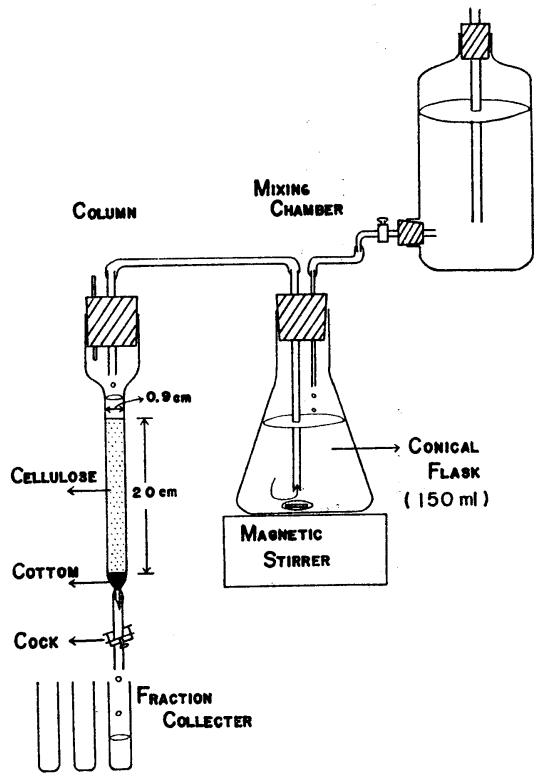

Fig. 1. Schema for gradient elution of column chromatography

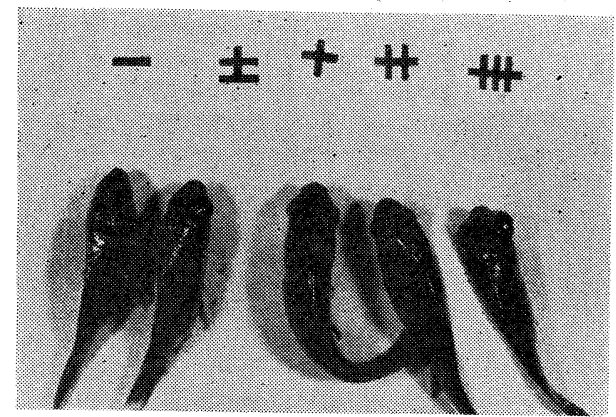

Fig. 2. The four gold fishes on the right treated with 10 JSU of Pretiron 5 hours previously. Control fish of $0.9 \%$ saline on the left.

抑制され，その放出抑制度と TSH 濃度との間には TSH $10^{-2} \mathrm{JSU} / \mathrm{ml}$ より $10^{-5} \mathrm{JSU} / \mathrm{ml}$ までの濃度範囲 において推計学上直線回帰が成立し，ての現象を利用 して血中 TSH 活性の測定を行なう方法である.

\section{7. 金魚の眼突反応の Bioassay}

著者は入手，飼育容易な市販の金魚の一品種である

和金 (Carassius auratus, var. japonicus) を用いた. 生後 1 年から 2 年の体長 $7 \mathrm{~cm}$ 前後, 体重 $4 \mathrm{gm}$ 前後 の和金 5 匹或いは10匹を一群とし，個々の識別には觰の一部を切除した. ガラス容器に塩素を抜いた水道水 を入れ, thermostat にて水温を $22^{\circ} \mathrm{C} \sim 24^{\circ} \mathrm{C}$ に保ち, サイフォンポンプにて絶えず空気を送つて飼育し, 実 験迄飼料は特に与えなかつた。試料の投与方法は Albert, ${ }^{2)}$ Dobyns and Wilson, ${ }^{15)}$ 又 Der Kinderen et al 16)の報告を参考にした. 即ち試料は朝 9 時頃に注射し，午後 2 時頃 (約 5 時間目)， 午後 7 時頃（約10時 間目), 翌朝 9 時頃 (約24時間目) 飞角膜間距離(Intercorneal Distance, 以下 ICD と略す) を測定

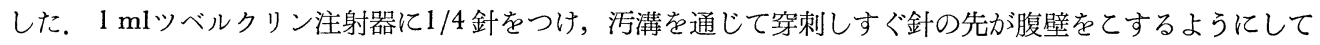
魚の長軸に平行に針を走らせ，内蔵に損傷のないようにし腹腔内に試料を注入した。注入後污溝より試料の 漏出しない事を確認してから水中に放出した。投与回数は 1 回, 投与量は体重 $10 \mathrm{gm}$ あたり $0.5 \mathrm{ml} の$ 割とし た. 即ち和金は大体 $4 \mathrm{gm}$ 程度であるので $0.2 \mathrm{ml}$ を注入するとととした. 眼突効果は試料注入前後の金魚の 左右角膜間距離を測定し, 注入前の IGD を100としててれに対する増加率, 即ち percent increase にて表 わした. ICD の測定には副尺のある鋼のノギス $(0.05 \mathrm{~mm}$ の精度 $)$ を用いて，1 匹につき 3 回測定して平 均值をとつた．測定には常に同じ人間があたり，光源の位置，ノギスや金魚の保持の仕方も一定にした. 注 入前の金魚の ICD は7〜10 mm であつた. Fig. 2 は金魚の眼突状態を示したものである.

\section{III 実 験 結 果}

\section{A 基礎的実験}

実験 1 自然放置下での金魚 ICD の経時的変動（Fig. 3, Table 1)

飼料を与えず水温 $24^{\circ} \mathrm{C}$ 亿自然放置した時の ICD の時間的変動を，2 日間追跡し朝，昼，夕の 3 回計測を 行なつた．最大変動はほぽ $\pm 3.5 \%$ で，2 日間ではえさを与えなくても特に瘦せて ICD に影響を与えるよ うなととはなく，著しい日内変動は認められなかつた，以下実験中はえさを与えることなく観察を行なつ た.

実験 2 機械的刺戟の ICD に及ぼす影響（Fig. 4, Table 2) 
Fig. 3. Diurnal variation of ICD on the gold fish $(n=10)$

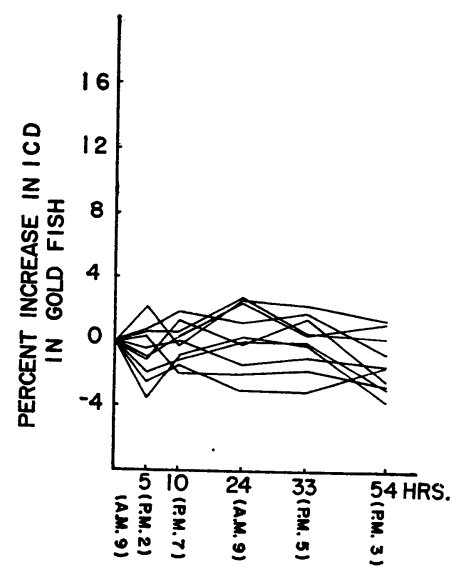

Fig. 4. Change of ICD after operative procedure. On the right cut off of fin. On the left puncture in cloaca $(\mathrm{n}=10)$
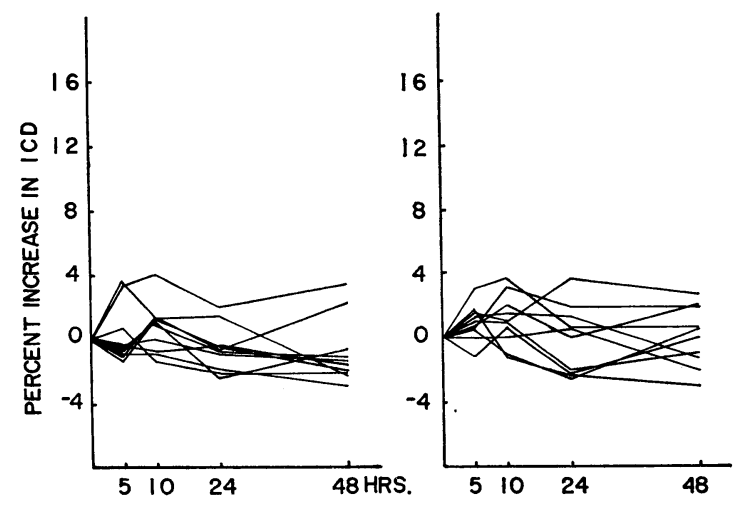

Table 1. Diurnal variation of ICD on the gold fish

\begin{tabular}{c|c|c|c|c|c}
\hline \multirow{2}{*}{} & \multicolumn{5}{|c}{ Percent increase in IGD } \\
\cline { 2 - 6 } & $5 \mathrm{hrs.}$ & $10 \mathrm{hrs.}$ & $24 \mathrm{hrs.}$ & $33 \mathrm{hrs}$. & 54hrs. \\
\hline \hline $\mathrm{n}=10$ & $-0.59 \pm 0.52$ & $-0.17 \pm 0.39$ & $0.31 \pm 0.65$ & $0.14 \pm 0.51$ & $-1.18 \pm 0.54$ \\
\hline
\end{tabular}

Table 2. Change of ICD after operative procedure

\begin{tabular}{c|c|c|c|c}
\hline & \multicolumn{3}{|c}{ Percent increase in ICD after operation } \\
\cline { 2 - 5 } & $5 \mathrm{hrs.}$ & $10 \mathrm{hrs.}$ & $24 \mathrm{hrs.}$ & $48 \mathrm{hrs.}$ \\
\hline \hline $\begin{array}{c}\text { Cut off of fin } \\
(\mathrm{n}=10)\end{array}$ & $0.28 \pm 0.57$ & $0.74 \pm 0.49$ & $-0.58 \pm 0.42$ & $-0.85 \pm 0.65$ \\
\hline $\begin{array}{c}\text { Puncture in cloaca } \\
(\mathrm{n}=10)\end{array}$ & $0.94 \pm 0.37$ & $1.09 \pm 0.51$ & $-0.12 \pm 0.68$ & $0.51 \pm 0.61$ \\
\hline
\end{tabular}

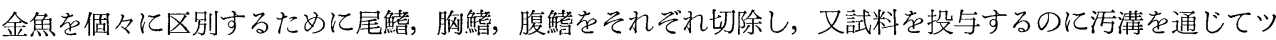
ベルクリン針を挿入するので，乙れ等の機械的刺㦸が ICD に影響を及ぼすか否かを検討した．即ち金魚の 鯺を切断し或いはツベルクリン針を泒溝を通じて挿入したあと経時的に ICD を測定した. その結果はFig. 4 そみられる如く土 $4 \%$ 以内の変動であつた。

実験 $30.9 \%$ 食塩水の ICD に及ぼす影響（Fig. 5, Table 3)

試料はすべて $0.9 \%$ 食塩水に溶解して実験に供したため，乙の溶媒による ICD の変化を観察した。和金 45匹に $0.9 \%$ 食塩水 $0.2 \mathrm{ml}$ を注射した後 $5 ， 10 ， 24 ， 48$ 時間目における ICD 增加率の $95 \%$ 信頼区間 (Confidence Interval) は図の如く $5 \%$ 以内である。このことから著者は $5 \%$ 迄の眼突度は正常範囲内の動 きと判定し， $5 \%$ 以上をもつて眼突陽性とした．尚以下の実験では必ず $0.9 \%$ 食塩水の対照群をとることに した。

実験 4 Pretiron 10JSU 投与の ICD に及ばす影響（Fig. 6, 7, Table 4)

\section{I ） 1 回投与}


Fig. 5. Influence on ICD after intracloacal injection of $0.5 \mathrm{ml}$ of $0.9 \%$ saline per $10 \mathrm{gm}$ body weight. $(n=45)$

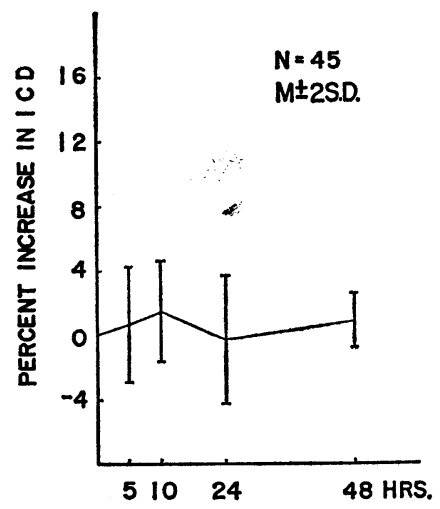

Fig. 6. Percent increase of ICD after single injection of $10 \mathrm{JSU}$ of Pretiron. $(n=10)$

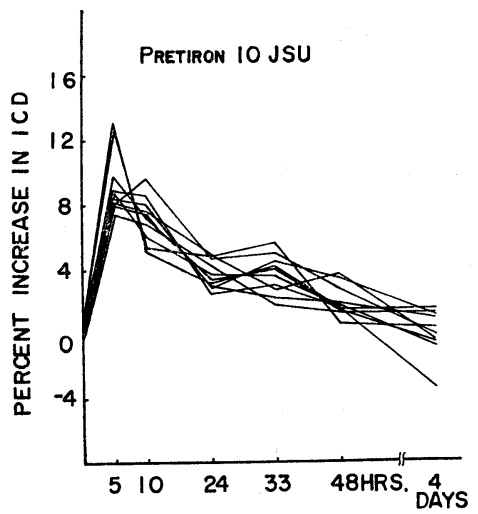

Table 3. Influence on ICD after intracloacal injection of $0.5 \mathrm{ml}$ of $0.9 \%$ $\mathrm{NaCl}$ per $10 \mathrm{gm}$ body weight $(\mathbf{M} \pm 2$ S.D. $)$

\begin{tabular}{c|c|c|c|c}
\hline \multirow{2}{*}{} & \multicolumn{4}{|c}{ Percent increase in ICD } \\
\cline { 2 - 5 } & $5 \mathrm{hrs.}$ & $10 \mathrm{hrs.}$ & $24 \mathrm{hrs.}$ & $48 \mathrm{hrs.}$ \\
\hline $\mathrm{N}=45$ & $0.69 \pm 3.6$ & $1.49 \pm 3.1$ & $-0.28 \pm 3.99$ & $0.86 \pm 1.7$ \\
\hline
\end{tabular}

Fig. 7. Percent increase of ICD after repeated injection of 10 JSU of Pretiron. $(n=10)$

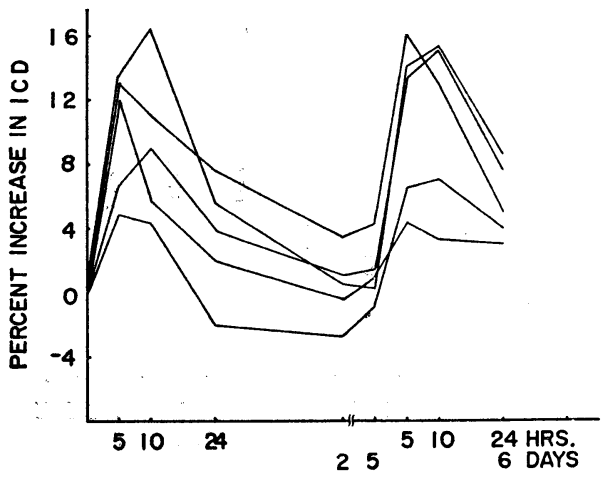

Fig. 8. Percent increase of ICD after injection of 5 JSU of Pretiron (hourly observed). $(\mathrm{n}=3)$

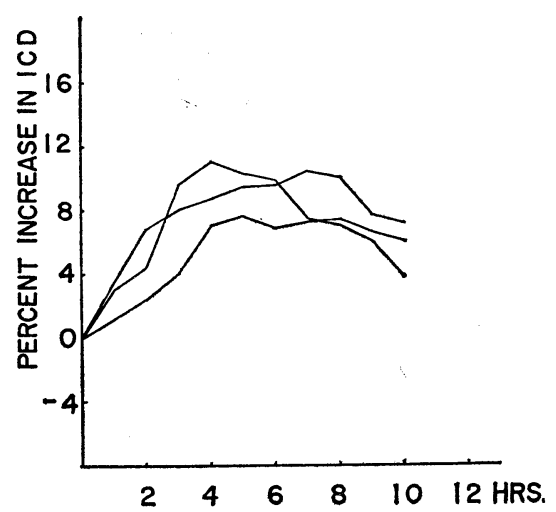

Table 4. Change of ICD after single injection of 10 JUS of Pretiron

\begin{tabular}{c|c|c|c|c|c|c}
\hline \multirow{2}{*}{} & \multicolumn{6}{|c}{ Percent increase in ICD } \\
\cline { 2 - 7 } & $5 \mathrm{hrs.}$ & $10 \mathrm{hrs.}$ & $24 \mathrm{hrs.}$ & $33 \mathrm{hrs.}$ & $48 \mathrm{hrs.}$ & 4 days \\
\hline \hline $\mathrm{n}=10$ & $9.33 \pm 0.65$ & $7.16 \pm 0.44$ & $3.74 \pm 0.27$ & $3.69 \pm 0.40$ & $1.93 \pm 0.31$ & $-0.27 \pm 0.44$ \\
\hline
\end{tabular}


Pretiron $10 \mathrm{JSU}$ を $0.9 \%$ 食塩水 $0.2 \mathrm{ml}$ に溶かし腹腔内注射後 5 時間目で ICD 増加率は $+9.33 \pm 0.65 \%$ と最高値を示し， 10 時間目では $+7.16 \pm 0.44 \%$ と減少の傾向を来たし， 24 時間目では全例急速に減少して $+3.74 \pm 0.27 \%$ と正常変動域に入り，48時間では更に減少し，約 4 日目で ICD は $-0.27 \pm 0.44 \%$ と正常に 復した。眼突の最高持続時間は約 5 時間である. 以後の実験においては Pretiron の標準をもとるととにし た.

\section{II） 2 回投与}

更に前回の実験にひき続き眼突の全く元に復した 5 日目に Pretiron 10 JSU を再投与したが，Fig. 7 の 如く 2 回目も 1 回目と殆んぞ同様の ICD の変動がみられ，眼笑反応は Pretiron により惹起されるのであ つて他の偶発因子によらないととを確認した。

\section{実験 5 Pretiron 注射後 1 時間毎のICD の変動（Fig. 8)}

Pretiron 注射後の ICD の変動を更に詳細に 1 時間毎に測定した。何れの場合も注射 1 時間後にすでに 増加傾向がみられ，早いものは 2 時間目に肉眼的眼突を示し， $3 \sim 4$ 時間後では全例に眼突著明，又 peak は 4〜 7 時間内に来るようで, 早いものは 5 時間目位から減少傾向か現われる.

実験 6 Pretiron の投与量亡眼突度との関係 (Fig. 9，10, Table 5)

Pretiron の夫々 $1.25,2.5,5.0 ， 10.0 ， 20.0 \mathrm{JSU}$ を計158匹の金魚の腹腔内に投与し， 5 時間後と10時 間後の ICD 增加率を比較検討した。投与 5 時間目（Fig. 9) では 1.25JSU 注射群（ $\mathrm{n}=21 ）$ は $3.49 \pm$ $0.51 \%, 2.5 \mathrm{JSU}$ 群 $(\mathrm{n}=28)$ では $6.06 \pm 0.87 \%, 5.0 \mathrm{JSU}$ 群 $(\mathrm{n}=26)$ では $8.29 \pm 1.11 \%, 10.0 \mathrm{JSU}$ 群 $(\mathrm{n}=$ 62) では $9.94 \pm 0.54 \%, 20.0 \mathrm{JSU}$ 群 $(\mathrm{n}=21)$ では $10.16 \pm 0.85 \%$ の増加率でありてれを図示すると Fig. 9 の

Fig. 9. Dose response of ICD after the injection of various doses of Pretiron (after 5 hours) $(\mathrm{n}=$ 158)

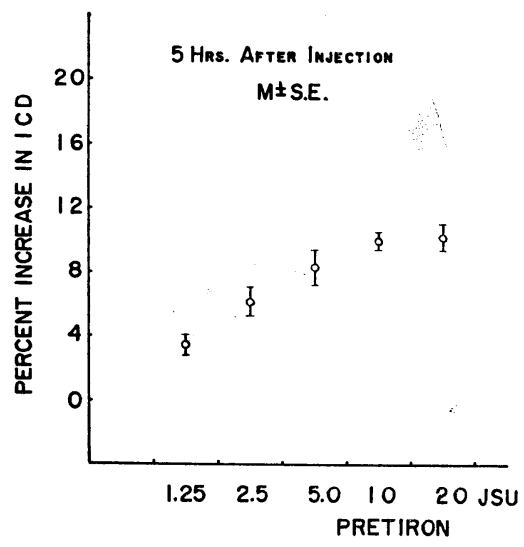

Fig. 10. Dose response of ICD after the injection of various doses of Pretiron (after 10 hours) (n $=158$ )

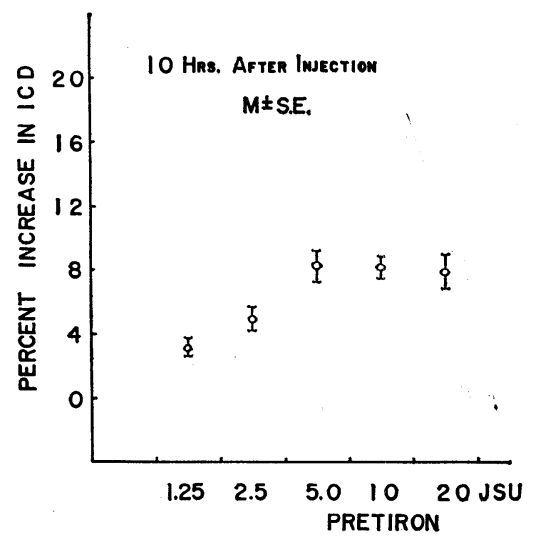

Table 5. Percent increase in ICD after the injection of various doses of Pretiron

\begin{tabular}{|c|c|c|c|c|c|c|}
\hline \multirow{2}{*}{\multicolumn{2}{|c|}{$\mathrm{n}=158$}} & \multicolumn{5}{|c|}{ Percent increase in ICD after injection of Pretiron } \\
\hline & & $\begin{array}{c}1.25 \text { JSU } \\
\mathrm{n}=21\end{array}$ & $\begin{array}{c}2.5 \mathrm{JSU} \\
\mathrm{n}=28\end{array}$ & $\begin{array}{r}5.0 \text { JSU } \\
\mathrm{n}=26\end{array}$ & $\begin{array}{c}10.0 \text { JSU } \\
\mathrm{n}=62\end{array}$ & $\begin{array}{c}20.0 \mathrm{JSU} \\
\mathrm{n}=21\end{array}$ \\
\hline \multirow{2}{*}{$\begin{array}{l}\text { Observation } \\
\text { time }\end{array}$} & $5 \mathrm{hrs}$. & $3.49 \pm 0.51$ & $6.06 \pm 0.87$ & $8.29 \pm 1.11$ & $9.94 \pm 0.54$ & $10.16 \pm 0.85$ \\
\hline & $10 \mathrm{hrs}$. & $3.19 \pm 0.38$ & $4.99 \pm 0.57$ & $8.37 \pm 1.03$ & $8.16 \pm 0.65$ & $7.8 \pm 1.07$ \\
\hline
\end{tabular}


如く, $1.25 \mathrm{JSU}$ から $10.0 \mathrm{JSU}$ の間では直線的增加 がみられた。投与10時間目では $1.25 \mathrm{JSU}$ 群は 3.19 $\pm 0.38 \%$ の増加率であり, $2.5 \mathrm{JSU}$ 群では $4.99_{ \pm} 0.57$ $\%, 5.0 \mathrm{JSU}$ 群では $8.37 \pm 1.03 \%, 10.0 \mathrm{JSU}$ 群では $8.16 \pm 0.65 \%, 20.0 \mathrm{JSU}$ 群では7.84 $1.07 \%$ を示し,

Fig. 10 の如く $1.25 \mathrm{JSU}$ から $5.0 \mathrm{JSU}$ の間でだけ直 線的增加を示した。即ち投与10時間目では実験 5 で述 た如く，すでに ICD の減少傾向のみられたものがあ るため, 直線的傾向が得られにくいものと思われる。

B Pretiron の Cellulose Column による分画

実験 1 CM-C (stepwise elution) による分画

(Fig. 11, 12, 13 Table 6, 7)

Fig.11は Pretiron 250JSU, 8.6mg (1.0ml に溶解) を $\mathrm{pH} 6.3,0.01 \mathrm{M}$ phosphate buffer 及び $1.0 \mathrm{M}$ $\mathrm{NaCl}$ で stepwise elution により展開した結果を示
Fig. 11. Column chromatography of Pretiron (250 JSU) on CMC Temp. $4^{\circ} \mathrm{C}$, Elute volume $21 \mathrm{ml} /$ hr., Solvents I : pH6.3, $0.01 \mathrm{M}$ Sodium phosphate II : stepwise change to $1.0 \mathrm{M}$ $\mathrm{NaCl}$

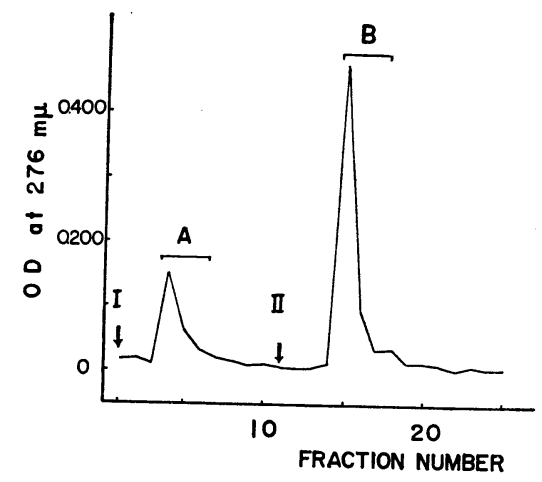

Fig. 12. Absorption spectrum of Fraction A, B and Pretiron ( $5 \mathrm{JSU} / \mathrm{ml}$ )

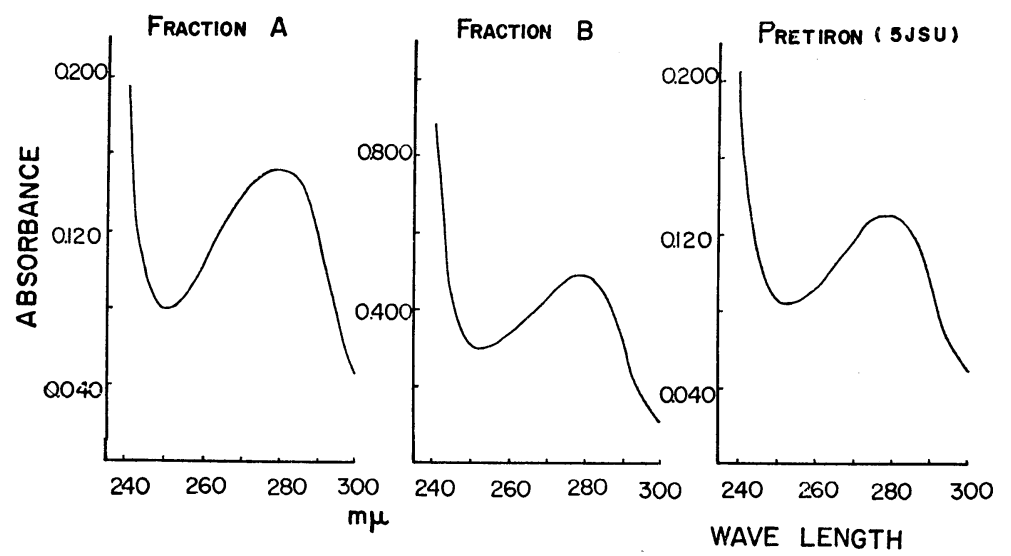

したもので, Tube No. 4〜6 (Fraction A) と, Tube No. 15〜17 (Fraction B) の二分 画を認めた。 各分画における最高值を示す Tube の吸収スペクトルの結果はFig.12で， $276 \mathrm{~m} \mu$ 附近に極大吸収を認めたが，両分画 とも Pretiron $5 \mathrm{JSU} / \mathrm{ml}$ の吸収スペクトル と同じ pattern を示した. Fraction A と Fraction B は凍結乾燥後 $0.9 \%$ 食塩水 $2.0 \mathrm{ml}$ に溶解し, TSH 活性を検定した結果は Table 6 の如くで, Fraction B に強い TSH 活性 が認められたが，Fraction A には殆んど見 る可き活性はなく $\mathrm{TSH}$ 回収率は 75.5\% で あつた，次に残りの試料で眼突活性を検定し
Fig. 13. EPS activity of Fraction A and B $(n=9)$
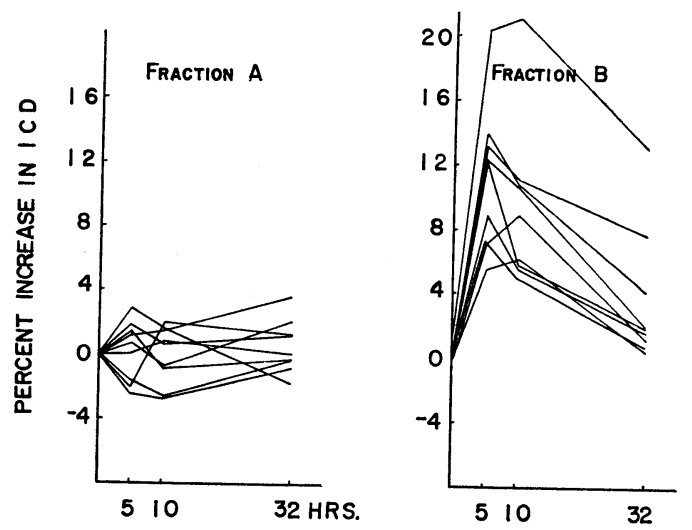
Table 6. TSH activity of each fractions on GM-G (stpwise elution)

\begin{tabular}{c|c}
\hline & TSH activity \\
\hline Fraction A & 0.156 JSU \\
\hline Fraction B & $188.50 \mathrm{JSU}$ \\
\hline
\end{tabular}

Table 7. EPS activity of Fraction A and B

\begin{tabular}{c|c|c|c}
\hline & \multicolumn{2}{|c|}{ Percent increase in ICD after injection of each fractions } \\
\cline { 2 - 4 } & $5 \mathrm{hrs.}$ & $10 \mathrm{hrs.}$ & $32 \mathrm{hrs}$. \\
\hline $\begin{array}{c}\text { Fraction A } \\
\mathrm{n}=9\end{array}$ & $1.14 \pm 0.71$ & $-0.01 \pm 0.59$ & $0.49 \pm 0.57$ \\
\hline $\begin{array}{c}\text { Fraction B } \\
\mathrm{n}=9\end{array}$ & $11.44 \pm 1.51$ & $9.42 \pm 1.66$ & $3.66 \pm 1.39$ \\
\hline
\end{tabular}

たのが Fig.13, Table 7 で, Fraction A では 5 時 間後の IGD 変化は $1.14 \pm 0.71 \%$ と正常範囲内にあ り, Fraction B では 5 時間值は $11.44 \pm 1.51 \%$ と 著明な眼突を示した. 即ち Fraction B に TSH と EPS の両活性が著明に認められた。 又 Fraction A の各試験管の吸光度の総計は246であり Fraction B の総計は605であつた。

実験 2 CM-C (gradient elution) による分画

(Fig.14, 15, 16, Table 8, 9)

Fig. 14は Pretiron 250JSU, 8.4mg ( $1 \mathrm{ml}$ に溶解) を $\mathrm{pH} 6.3,0.01 \mathrm{M}$ phsphate buffer のあと $1.0 \mathrm{M}$ $\mathrm{NaCl}$ で gradient elution を行なつたもので, 同 じく二つの peak が得られたが NaCl buffer の gradient elution の所では tailing した展開が得ら
Fig. 14. Column chromatography of Pretiron (250 JSU) 'on CM-G Temp. $0^{\circ} \mathrm{C}$, Elute volume $20 \mathrm{ml} / \mathrm{hr}$., Solvents I : $\mathrm{pH} 6.3,0.01 \mathrm{M}$ Sodium phosphate II : gradient change to $1.0 \mathrm{M} \mathrm{NaCl}$

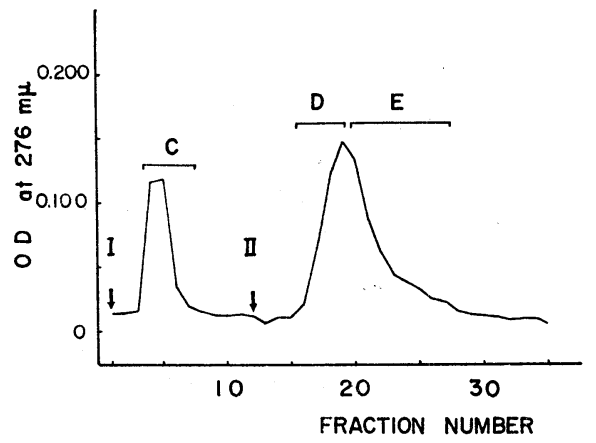

Fig. 15. Absorption spectrum of Fraction C,D,E and Pretiron (5 JSU/ml)
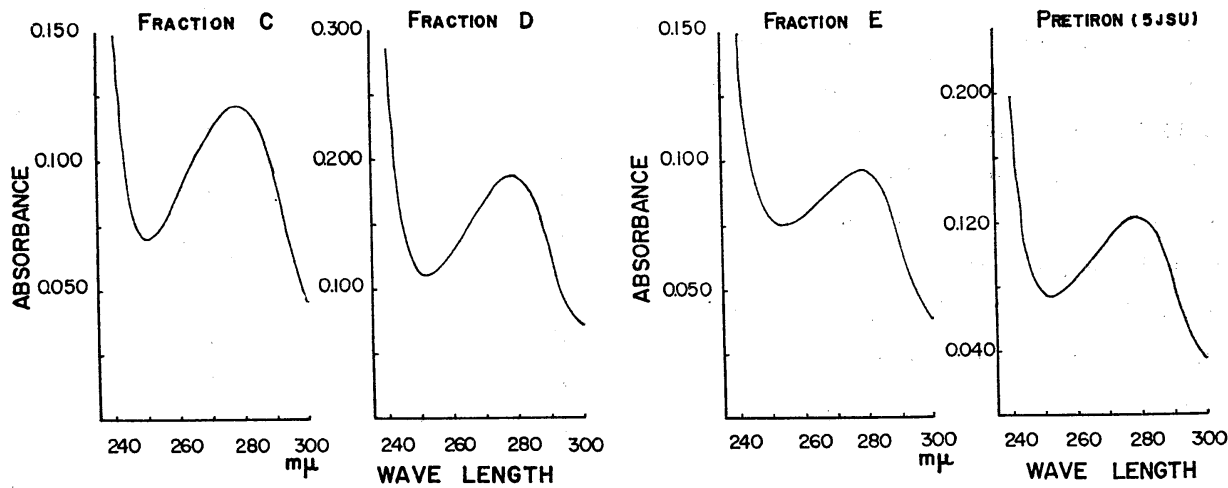
れた. この部分を前後二つの Fraction に分 け Tube No. 4〜7 を Fraction C, Tube No. 16〜19 を Fraction D, Tube No. 20 27 を Fraction Eとした。 Fig.15 は各分画 の最高值を示す Tube の吸収スペクトルを 示したもので，いずれも $276 \mathrm{~m} \mu$ 附近で極大 吸収を認めた。

TSH 活性は Table 8 の如く Fraction D r 少こし認められるが圧倒的に Fraction E に 強く, $\mathrm{TSH}$ 回収率は $87.45 \%$ であつた. 又 眼突活性は Fig. 16，Table 9 の如く 5 時間値 では Fraction C は $0.47 \pm 0.27 \%$, Fraction D
Fig. 16. EPS activity of Fraction C, D and $\mathrm{E}(\mathrm{n}=9)$

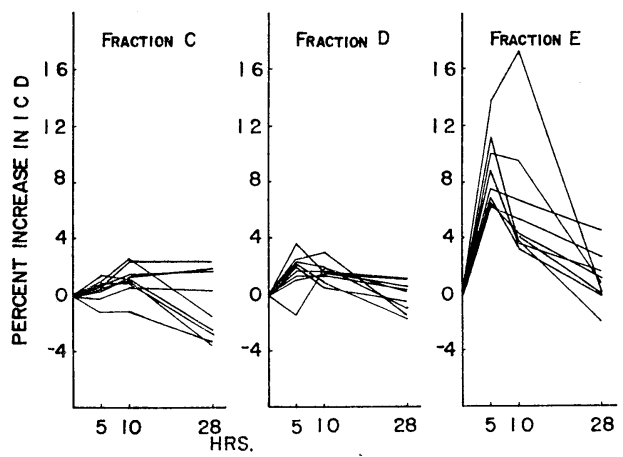

Table 8. TSH activity of each fractions on GM-C (gradient elution)

\begin{tabular}{c|c}
\hline & TSH activity \\
\hline \hline Fraction G & $0.404 \mathrm{JSU}$ \\
\hline Fraction D & $6.24 \mathrm{JSU}$ \\
\hline Fraction E & $212.0 \mathrm{JSU}$ \\
\hline
\end{tabular}

Table 9. EPS activity of Fraction $\mathrm{C}, \mathrm{D}$ and $\mathrm{E}$

\begin{tabular}{c|c|c|c}
\hline & \multicolumn{2}{|c}{ Percent increase in ICD after injection of each fractions } \\
\cline { 2 - 4 } & $5 \mathrm{hrs.}$ & $10 \mathrm{hrs.}$ & $28 \mathrm{hrs}$. \\
\hline $\begin{array}{c}\text { Fraction C } \\
\mathrm{n}=9\end{array}$ & $0.47 \pm 0.27$ & $1.13 \pm 0.37$ & $-0.87 \pm 0.80$ \\
\hline $\begin{array}{c}\text { Fraction D } \\
\mathrm{n}=9\end{array}$ & $1.17 \pm 0.48$ & $1.56 \pm 0.29$ & $-0.18 \pm 0.36$ \\
\hline $\begin{array}{c}\text { Fraction E } \\
\mathrm{n}=9\end{array}$ & $8.88 \pm 0.82$ & $6.39 \pm 1.52$ & $0.95 \pm 0.62$ \\
\hline
\end{tabular}

は $1.17 \pm 0.48 \%$ で全然活性はなく，Fraction E に $8.88 \pm 0.82 \%$ と著明な眼突が認められた。乙のように gradient elution を試みて TSH と EPS を分離しょうとしたが，TSHも EPS も同様の態度をとり分離 出来なかつた. 又 Fraction G の各試験管の吸光度の総計は270であり, Fraction D の総計は 356 であり Fraction E の総計は444であつた。

実験 3 DEAE-C (stepwise elution) による分画 (Fig.17, 18, 19, Table 10, 11)

Pretiron 375JSU, $12.2 \mathrm{mg}$ (1.5ml に溶解) を $\mathrm{pH}$ 9.5, 0.005M glycine-NaOH bufferのあとは stepwise elution にて pH 9.5, 0.1M glycine- $\mathrm{NaOH}$ buffer, $0.2 \mathrm{M} \mathrm{NaH} \mathrm{PO}_{4}, 1.0 \mathrm{M} \mathrm{NaCl}$ の順で展開した結果が Fig.17である. 図の如く4つの peak が得られたが Tube No. 6〜8 を Fraction F, Tube No. 19〜22 を Fraction G, Tube No. 33〜36 を Fraction H, Tube No. 45〜47 を Fraction I とし, 各分画の最高值を 示す tube の吸収スペクトルはFig.18に示してある. Fraction F,G,H では $276 \mathrm{~m} \mu$ 附近に極大吸収が認め られ，Fraction I でも同じ波長の所に吸収を認めた。各 Fraction の TSH 活性は Table 10 に示してある

$$
\text { 第 } 40 \text { 巻 第 } 8 \text { 号 }
$$


Fig. 17. Column chromatography of Pretiron (375 JSU) on DEAE-C Temp. $4^{\circ} \mathrm{C}$, Elute volume $18 \mathrm{ml} / \mathrm{hr}$., Solvents I : $\mathrm{pH}$ 9.5, 0.005M Sodium glycinate II : stepwise change to $\mathrm{pH} 9.5,0.1 \mathrm{M}$ sodium glycinate III : stepwise change to $0.2 \mathrm{M} \mathrm{NaH}{ }_{2} \mathrm{PO}_{4} \mathrm{IV}$ : stpwise change to $1.0 \mathrm{M} \mathrm{NaCl}$

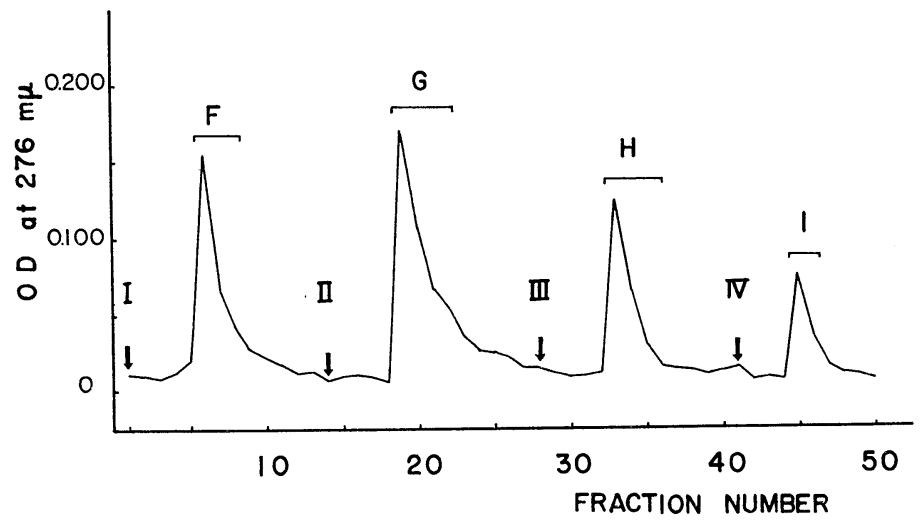

Fig. 18. Absorption spectrum of Fraction F,G,H,I and Pretiron (5 JSU/ml)
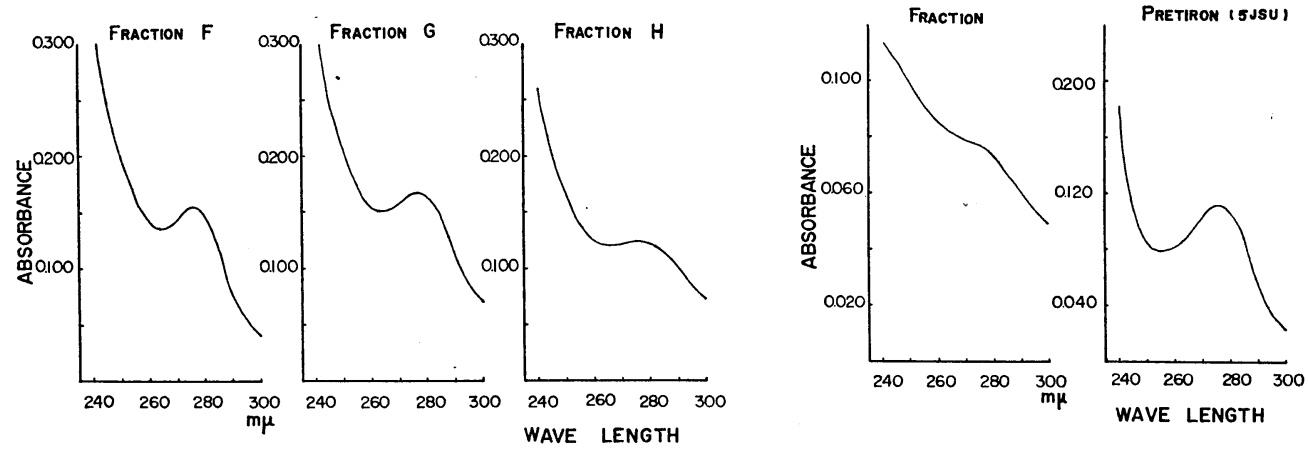

Fig. 19. EPS activity of Fraction F,G,H and I. $(n=10)$
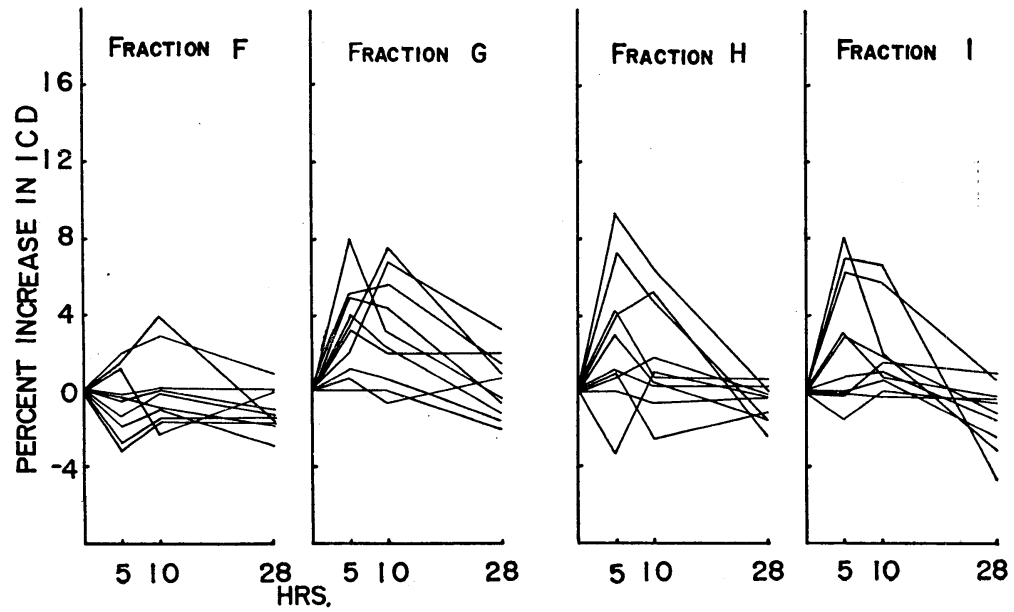

第 40 巻 第 8 号 
Table 10. TSH activity of each fractions on DEAE-C

\begin{tabular}{c|c}
\hline & TSH activity \\
\hline \hline Fraction F & 0.442 JSU \\
\hline Fraction G & $2.014 \mathrm{JSU}$ \\
\hline Fraction H & $322.0 \mathrm{JSU}$ \\
\hline Fraction I & $0 \mathrm{JSU}$ \\
\hline
\end{tabular}

Table 11. EPS activity of Fraction F,G, H, and I

\begin{tabular}{c|c|c|c}
\hline & Percent increase in ICD after injection of each fractions \\
\cline { 2 - 4 } & $5 \mathrm{hrs.}$ & $10 \mathrm{hrs.}$ & $28 \mathrm{hrs.}$ \\
\hline \hline $\begin{array}{c}\text { Fraction F } \\
\mathrm{n}=10\end{array}$ & $-0.49 \pm 0.70$ & $-0.12 \pm 0.68$ & $-1.04 \pm 0.42$ \\
\hline $\begin{array}{c}\text { Fraction G } \\
\mathrm{n}=10\end{array}$ & $3.28 \pm 1.01$ & $3.21 \pm 1.03$ & $0.29 \pm 0.51$ \\
\hline $\begin{array}{c}\text { Fraction H } \\
\mathrm{n}=10\end{array}$ & $2.79 \pm 1.34$ & $1.78 \pm 1.16$ & $-0.61 \pm 0.38$ \\
\hline $\begin{array}{c}\text { Fraction I } \\
\mathrm{n}=10\end{array}$ & $2.66 \pm 1.03$ & $1.98 \pm 0.94$ & $-1.34 \pm 0.53$ \\
\hline
\end{tabular}

通り Fraction F.G には TSH 活性が極めて低く, Fraction I では全く認められず Fraction H に著 明に集まり TSH 回集率は86.5\%であつた。眼突活性は Fig. 19, Table 11の如くFraction F では正常範囲 内の変化であるが，Fraction G,H,I では眼突反応の悪い例もあるが $5 \%$ を越す例が認められ眼突活性は Fraction G,H,I に分散して現われた. 又 Fraction F の各試験管の吸光度の総計は262であり，Fraction G の総計は395であり, Fraction H の総計は235であり Fraction I の総計は109であつた.

C 乾燥甲状腺末 (Thyradine)，Thyroxine $\left(\mathbf{T}_{4}\right)$ ，Triiodothyronine $\left(\mathbf{T}_{3}\right)$ の前処置が Pretiron の眼突作用に及 ぼす影響

実験 1 Thyradine のICD に及ぼす影響（Fig.20, 21，22, Table 12)

Fig. 20. Effect of $0.5 \mathrm{ml}$ of $0.9 \% \mathrm{NaCl}$ per $10 \mathrm{gm}$ body weight on ICD $(n=10)$

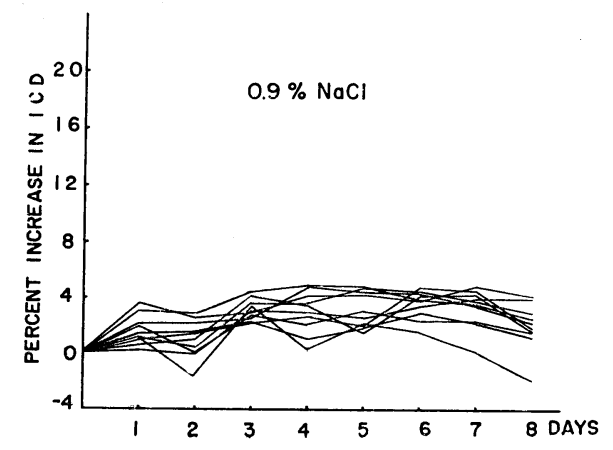

Fig. 21. Effect of Thyradine of $5 \mathrm{mg}$ on ICD $(\mathrm{n}=8)$

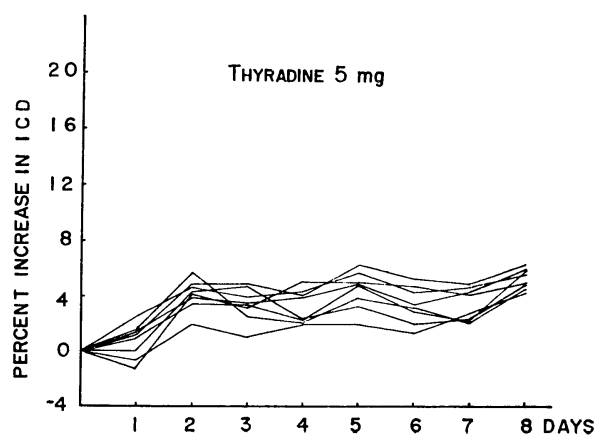


Thyradine $5 \mathrm{mg}, 20 \mathrm{mg}$ の投与が和金の ICD に及ぼす効果を 8 日間観察した。 $5 \mathrm{mg}$ 投与の場合の最高変化は $4.49 \pm 0.49 \%$ で, $0.9 \%$ 食塩水での対照 (Fig. 20$)$ と同様に ICD の変化は正常範囲内であつたが，20mg 投与の場合は 4 日目に $6.71 \pm 0.99 \%$ とかなり の眼突を来たし，その内 2 例は肉眼的に判别 出来る程度の眼突であり, Thyradine 大量 投与では眼突惹起作用のあることが分つた。

実験 $2 \mathrm{~T}_{4}$ の ICD に及ぼす影響（Fig. 23 24, Table 12)

$\mathrm{T}_{4} 5 \gamma, 50 \gamma$ の投与に依る ICD への影響
Fig. 22. Effect of Thyradine 20mg on ICD.

$$
(\mathrm{n}=7)
$$

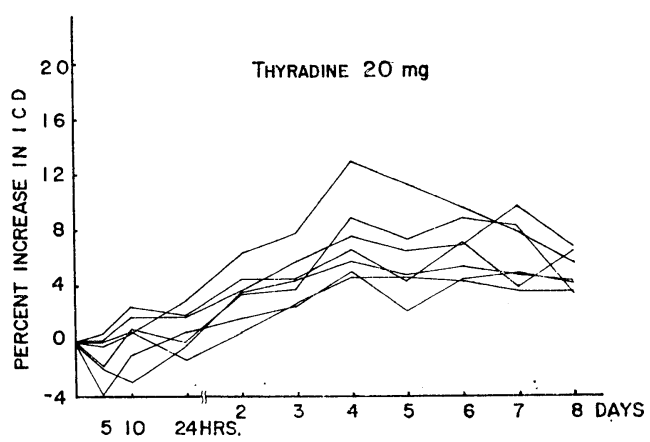

Table 12. Change of ICD for 8 days after injection of thyroid hormones

\begin{tabular}{|c|c|c|c|c|c|c|c|c|c|}
\hline & & \multicolumn{8}{|c|}{ Percent increase in ICD } \\
\hline & & lday & 2days & 3days & 4days & 5days & 6days & 7 days & 8days \\
\hline \multicolumn{2}{|l|}{$\begin{array}{c}0.9 \% \mathrm{NaCl} \\
\mathrm{n}=10\end{array}$} & $\begin{array}{l}1.67 \pm \\
0.34\end{array}$ & $\begin{array}{l}1.03 \pm \\
0.43\end{array}$ & $\begin{array}{l}3.14 \pm \\
0.29\end{array}$ & $\begin{array}{l}3.14 \pm \\
0.48\end{array}$ & $\begin{array}{l}3.67 \pm \\
0.60\end{array}$ & $\begin{array}{l}4.04 \pm \\
0.40\end{array}$ & $\begin{array}{l}4.12 \pm \\
0.62\end{array}$ & $\begin{array}{l}2.41 \pm \\
0.66\end{array}$ \\
\hline \multirow{2}{*}{$\begin{array}{c}\text { Desiccated } \\
\text { thyroid }\end{array}$} & $\left|\begin{array}{l}5 \mathrm{mg} \\
\mathrm{n}=8\end{array}\right|$ & $\left|\begin{array}{l}0.68 \pm \\
0.43\end{array}\right|$ & $\begin{array}{l}4.11 \pm \\
0.38\end{array}$ & $\begin{array}{l}3.37 \pm \\
0.44\end{array}$ & $\begin{array}{l}3.11 \pm \\
0.43\end{array}$ & $\begin{array}{l}4.49 \pm \\
0.49\end{array}$ & $\begin{array}{l}3.38 \pm \\
0.47\end{array}$ & $\begin{array}{l}3.37 \pm \\
0.41\end{array}$ & $\begin{array}{l}4.21 \pm \\
0.22\end{array}$ \\
\hline & $\begin{array}{l}20 m g \\
n=7\end{array}$ & $\begin{array}{l}0.81 \pm \\
0.56\end{array}$ & $\begin{array}{l}3.49= \\
0.61\end{array}$ & $\begin{array}{l}4.47= \\
0.69\end{array}$ & $\begin{array}{l}6.71 \pm \\
0.99\end{array}$ & $\begin{array}{l}5.86 \pm \\
1.11\end{array}$ & $\begin{array}{l}6.60 \pm \\
0.79\end{array}$ & $\begin{array}{l}6.41 \pm \\
0.87\end{array}$ & $\begin{array}{l}4.96 \pm \\
0.57\end{array}$ \\
\hline \multirow{2}{*}{ Thyroxine } & $\left|\begin{array}{c}5 \gamma \\
\mathrm{n}=8\end{array}\right|$ & $\left|\begin{array}{l}-1.61 \pm \\
0.74\end{array}\right|$ & $\left|\begin{array}{l}-0.65 \pm \\
0.72\end{array}\right|$ & $\left|\begin{array}{l}-0.03 \pm \\
0.98\end{array}\right|$ & $\left|\begin{array}{l}-1.81 \pm \\
0.92\end{array}\right|$ & $\left|\begin{array}{l}-0.57 \pm \\
0.83\end{array}\right|$ & $|-1.71 \pm|$ & $\left|\begin{array}{l}-0.72 \pm \\
0.89\end{array}\right|$ & $\begin{array}{l}1.53 \pm \\
0.74\end{array}$ \\
\hline & $\begin{array}{c}50 \gamma \\
\mathrm{n}=8\end{array}$ & $\begin{array}{l}-2.09 \pm \\
0.74\end{array}$ & $\mid \begin{array}{l}-0.94 \\
0.67\end{array}$ & $\mid \begin{array}{l}-0.32 \pm \\
0.65\end{array}$ & $|-1.22 \pm|$ & $\begin{array}{l}0.39 \pm \\
0.49\end{array}$ & $\mid \begin{array}{l}-0.82 \pm \\
0.72\end{array}$ & $|-1.10 \pm|$ & $\mid \begin{array}{l}-0.68 \pm \\
0.71\end{array}$ \\
\hline \multirow{2}{*}{ Triiodothyronine } & $\left|\begin{array}{c}0.5 \gamma \\
\mathrm{n}=7\end{array}\right|$ & $\begin{array}{l}2.38 \pm \\
0.41\end{array}$ & $\begin{array}{l}4.29 \pm \\
0.86\end{array}$ & $\begin{array}{l}3.73 \pm \\
0.54\end{array}$ & $\begin{array}{l}2.89 \pm \\
0.59\end{array}$ & $\begin{array}{l}3.59 \pm \\
0.79\end{array}$ & $\begin{array}{l}3.18 \pm \\
0.64\end{array}$ & $\begin{array}{l}3.09 \pm \\
0.76\end{array}$ & $\begin{array}{l}2.46 \pm \\
0.42\end{array}$ \\
\hline & $\begin{array}{c}2 \gamma \\
n=8\end{array}$ & $\begin{array}{l}2.33 \pm \\
0.71\end{array}$ & $\begin{array}{l}4.02 \pm \\
0.73\end{array}$ & $\begin{array}{l}4.27 \pm \\
0.77\end{array}$ & $\begin{array}{l}2.04 \pm \\
0.66\end{array}$ & $\begin{array}{l}2.63 \pm \\
0.46\end{array}$ & $\begin{array}{l}2.84 \pm \\
0.75\end{array}$ & $\begin{array}{l}2.46 \pm \\
0.64\end{array}$ & $\begin{array}{l}1.88 \pm \\
0.74\end{array}$ \\
\hline
\end{tabular}

Fig. 23. Effect of Thyroxine $5 \gamma$ on ICD $(\mathbf{n}=\mathbf{8})$

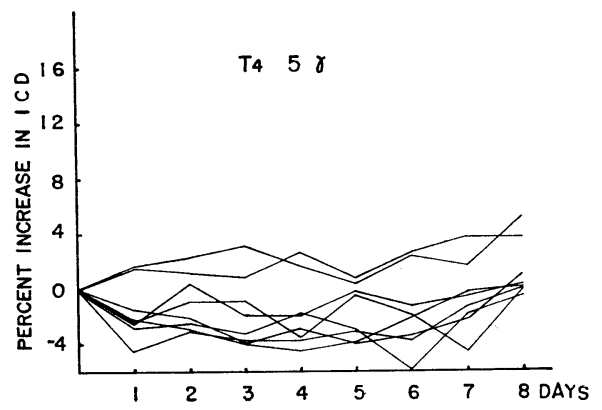

Fig. 24. Effect of Thyroxine $50 \gamma$ on ICD $(n=8)$

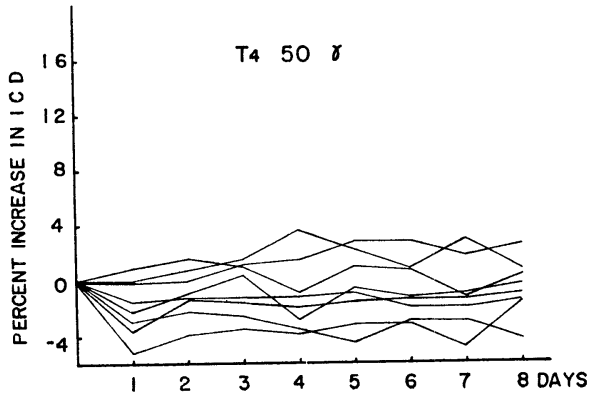


Fig. 25. Effect of Triiodothyronine $0.5 \gamma$ on ICD $(n=7)$

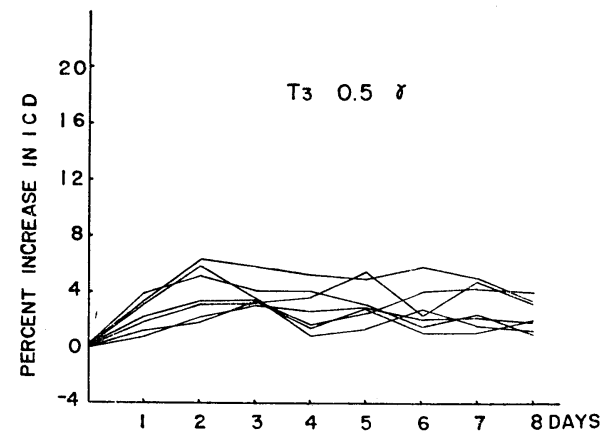

Fig. 26. Effect of Triiodothyronine $2 \gamma$ on ICD $(n=8)$

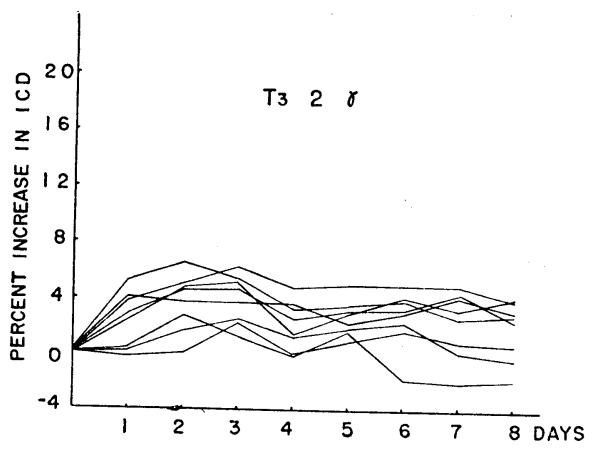

はFig.23，24の如く正常範囲内の動きであり，T 4 には眼突作用は認められなかつた。

実験 $3 \mathrm{~T}_{3}$ の ICD に及ぼす影響（Fig.25，26，Table 12)

$\mathrm{T}_{3} 0.5 \gamma, 2 \gamma$ の投与ではFig. $25 ， 260$ 如く両者共 2 例に投与 2 日目から 3 日目に軽度眼突を示したが，肉 眼的に識別出来る程度ではなく，他は全く正常範囲内の ICD 変化であつた。 この結果 $\mathrm{T}_{3}$ には著明な眼突 作用はないと云える。

実験 4 Thyradine 前処置後 Pretiron の投与 (Fig. 27, 28, Table 13)

Thyradine $20 \mathrm{mg}$ 投与後甲状腺ホルモンの末梢組織への作用の現われていると思われる 3 日目 ${ }^{17}$ に, Pretiron 5JSU を注射し Pretiron の眼突活性の影響のされ方を観察したのがFig.28である．2 例において 対照（Fig.27）よりむしろ著明な眼突を来たしたが残りは対照と同程度であり，Thyradine 前処置は Pretiron の眼突作用に殆んぞ影響を与えないものと思われる。

実験 $5 \quad T_{4}$ 前処置後 Pretiron の投与 (Fig.30, Table 13)

$\mathrm{T}_{4} 50 \gamma$ を投与し前実験と同様. Pretiron 5JSU を 3 日目に注射した例 (Fig.29) でも, 対照 (Fig.27) と 同様であり有意の差はなかつた。

実験 $6 \mathrm{~T}_{3}$ 前処置後 Pretiron の投与 (Fig.29, Table 13)

$T_{3}$ は末梢組織での作用発現が早いため ${ }^{17)} T_{3} 2 \gamma$ 投与後 24 時間目に Pretiron $5 J S U$ を投与したが，この

Fig. 27. Change of ICD after injection of 5 JSU of Pretiron on the 3rd day following pretreatment with $0.9 \%$ $\mathrm{NaCl}(\mathrm{n}=9)$

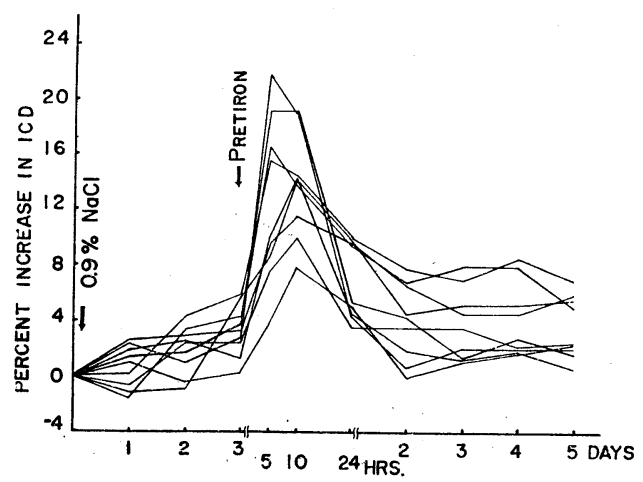

Fig. 28. Change of ICD after injection of $5 \mathrm{JSU}$ of Pretiron on the 3rd day following pretreatment with $20 \mathrm{mg}$ of Thyradine $(\mathrm{n}=7)$

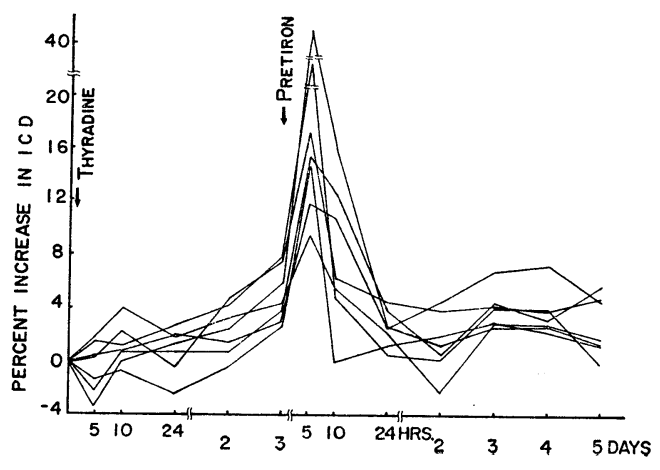


Table 13. Change of ICD in gold fishes after injection of 5 JSU of Pretiron on the 3rd day following pretreatment with thyroid hormones

\begin{tabular}{|c|c|c|c|c|c|c|c|c|c|c|}
\hline & \multicolumn{10}{|c|}{ Percent increase in ICD after injection of } \\
\hline & \multicolumn{3}{|c|}{ Thyroid hormones } & \multicolumn{7}{|c|}{ Pretiron } \\
\hline & lday & 2days & 3days & 5hrs. & 10hrs. & $24 \mathrm{hrs}$. & 2days & 3days & 4days & 5 days \\
\hline $\begin{array}{c}0.9 \% \quad \mathrm{NaCI} \\
\mathrm{n}=9\end{array}$ & $\begin{array}{l}0.80 \pm \\
0.56\end{array}$ & $\begin{array}{l}2.04 \pm \\
0.58\end{array}$ & $\begin{array}{l}3.21 \pm \\
0.80\end{array}$ & $\begin{array}{l}12.43 \pm \\
1.93\end{array}$ & $\begin{array}{l}13.66 \pm \\
1.23\end{array}$ & \begin{tabular}{|l|}
$6.74 \pm$ \\
0.91
\end{tabular} & $\begin{array}{l}3.99 \pm \\
0.88\end{array}$ & $\begin{array}{l}3.77 \pm \\
0.84\end{array}$ & $\begin{array}{l}4.08 \pm \\
0.87\end{array}$ & $\begin{array}{l}3.63 \pm \\
0.74\end{array}$ \\
\hline $\begin{array}{l}\text { Desiccated } \\
\text { thyroid } \\
20 \mathrm{mg} \mathrm{n}=7\end{array}$ & $\begin{array}{l}0.83 \pm \\
0.64\end{array}$ & $\begin{array}{l}2.36 \pm \\
0.70\end{array}$ & $\begin{array}{l}5.04 \pm \\
0.79\end{array}$ & $\begin{array}{l}19.42 \pm \\
4.10\end{array}$ & $\begin{array}{l}7.96 \pm \\
2.04\end{array}$ & $\begin{array}{l}2.57 \pm \\
0.51\end{array}$ & $\begin{array}{l}1.53 \pm \\
0.87\end{array}$ & $\begin{array}{l}4.05 \pm \\
0.54\end{array}$ & $\begin{array}{l}3.09 \pm \\
0.69\end{array}$ & $\begin{array}{l}2.82 \pm \\
0.26\end{array}$ \\
\hline $\begin{array}{l}\text { Thyroxine } \\
50 \gamma \quad \mathrm{n}=6\end{array}$ & $\left|\begin{array}{l}-3.17 \pm \\
1.10\end{array}\right|$ & $\left|\begin{array}{l}-0.76 \pm \\
0.98\end{array}\right|$ & $\left|\begin{array}{l}-2.62 \pm \\
0.46\end{array}\right|$ & $\begin{array}{l}11.43 \pm \\
1.88\end{array}$ & $\begin{array}{l}9.34 \pm \\
2.25\end{array}$ & $\left|\begin{array}{l}-0.49 \pm \\
1.53\end{array}\right|$ & $\mid \begin{array}{l}-2.61 \pm \\
0.59\end{array}$ & $\left|\begin{array}{l}-2.92 \pm \\
1.38\end{array}\right|$ & $\left|\begin{array}{l}-3.40 \pm \\
1.15\end{array}\right|$ & $\mid \begin{array}{l}-2.63 \pm \\
1.23\end{array}$ \\
\hline $\begin{array}{l}\text { Triiodothy- } \\
\text { ronine } 2 \gamma \\
\mathrm{n}=7 *\end{array}$ & $\mid \begin{array}{l}-0.86 \pm \\
0.29\end{array}$ & 1 & 1 & $\begin{array}{l}5.17 \pm \\
0.42\end{array}$ & $\begin{array}{l}4.69 \\
0.63\end{array}$ & $\begin{array}{l}0.79 \pm \\
0.59\end{array}$ & $\begin{array}{l}1.33 \pm \\
0.62\end{array}$ & $\begin{array}{l}1.46 \pm \\
0.70\end{array}$ & $\begin{array}{l}1.75 \pm \\
0.49\end{array}$ & $\begin{array}{l}2.00 \pm \\
0.78\end{array}$ \\
\hline
\end{tabular}

* Pretiron was injected on the 24th hour following pretreatment with Triiodothyronine.

Fig. 29. Ghange of ICD after injection of 5 JSU of Pretiron on the 3rd day following pretreatment with $50 \gamma$ of Thyroxine $(\mathrm{n}=6)$

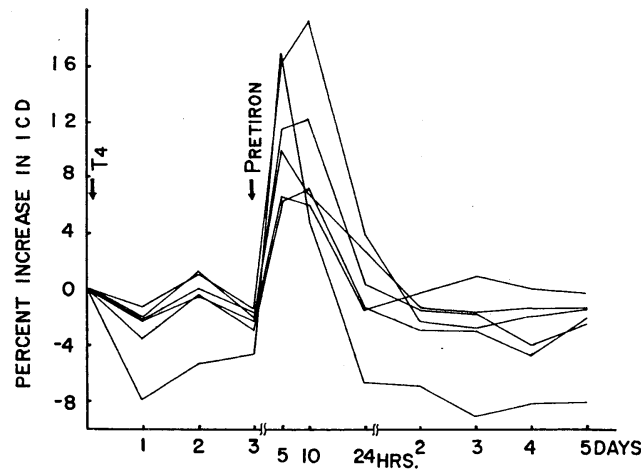

Fig. 31. Change of ICD after simultaneous injection of $0.9 \% \mathrm{NaCl}$ and $5 \mathrm{JSU}$ of Pretiron $(n=5)$

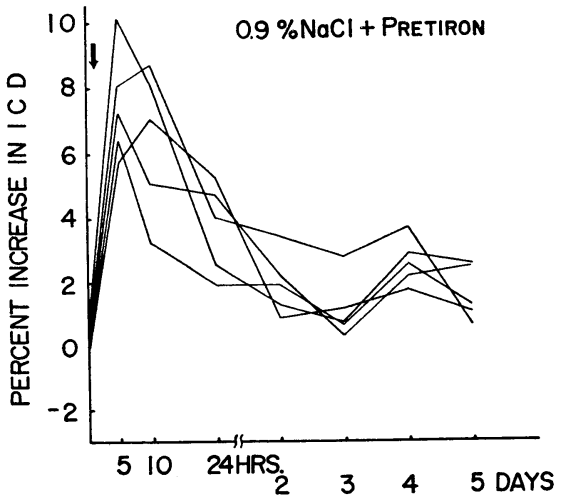

Fig. 30. Change of ICD after injection of $5 \mathrm{JSU}$ of pretiron on the 24 th hourt following pretreatmen with $2 \gamma$ of Triiodothyronine $(n=7)$

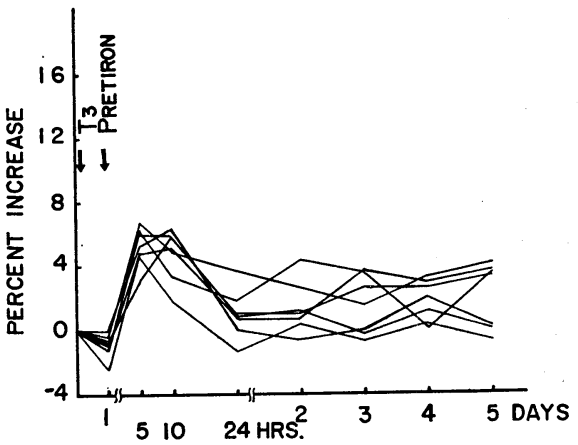

Fig. 32. Change of ICD after simultaneous injection of $20 \mathrm{mg}$ of Thyradine and 5JSU of Pretiron $(n=5)$

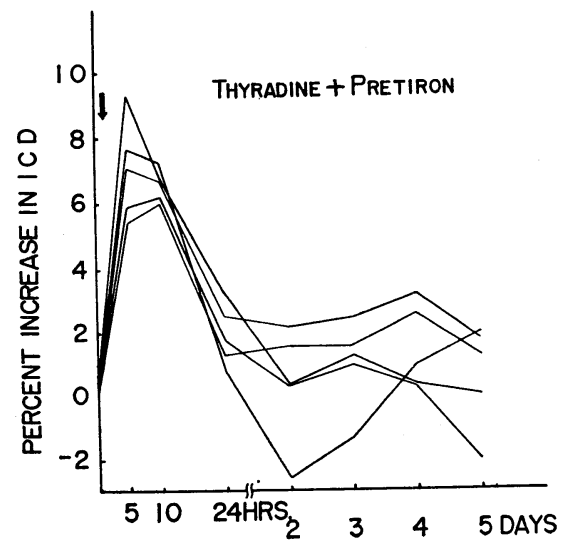


Fig. 33. Change of ICD after simultaneous injection of $50 \gamma$ of Thyroxine and 5 JSU of Pretiron. $(n=5)$

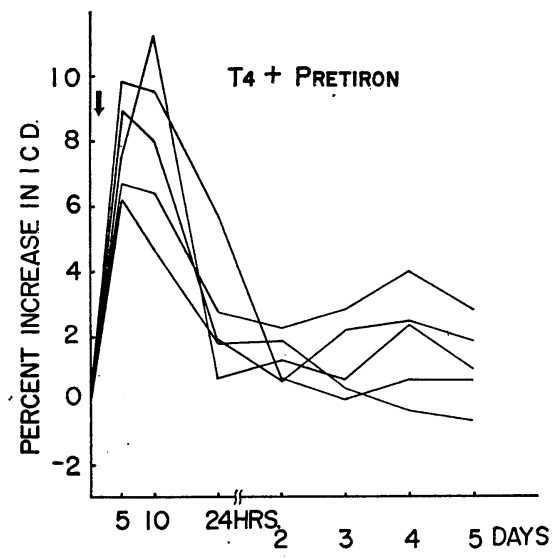

Fig. 34. Change of ICD after simultaneous injection of $2 \gamma$ of Triiodothyronine and 5JSU of Pretiron. $(n=5)$

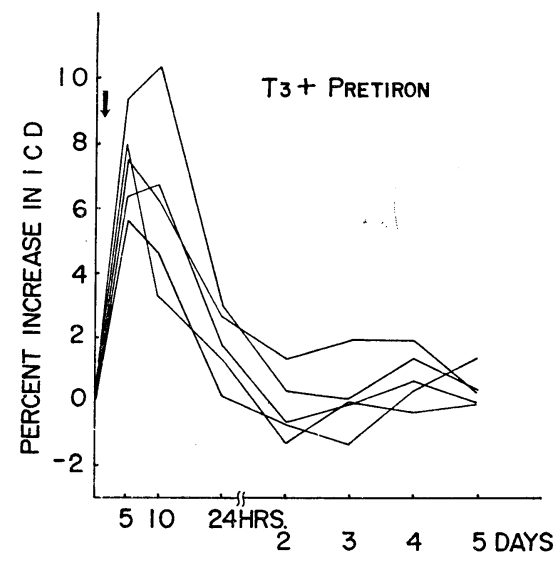

Table 14. Change of ICD after simultaneous injection of thyroid hormones and 5 JSU of Pretiron

\begin{tabular}{|c|c|c|c|c|c|c|c|}
\hline & \multicolumn{7}{|c|}{ Percent increase in ICD } \\
\hline & 5 hrs. & $10 \mathrm{hrs}$ & $24 \mathrm{hrs}$ & 2 days & 3days & 4days & 5 days \\
\hline $\begin{array}{c}0.9 \% \mathrm{HaCl} \\
\mathrm{n}=5\end{array}$ & $7.52 \pm 0.77$ & $6.42 \pm 1.09$ & $3.69 \pm 0.53$ & $1.94 \pm 0.44$ & $1.11 \pm 0.44$ & $2.63 \pm 0.27$ & $1.62 \pm 0.39$ \\
\hline $\begin{array}{l}\text { Desiccated thyrid } 20 \mathrm{mg} \\
\mathrm{n}=5\end{array}$ & $8.35 \pm 1.49$ & $8.11 \pm 1.54$ & $1.62 \pm 0.74$ & $0.34 \pm 0.83$ & $30.99 \pm 0.64$ & $1.28 \pm 0.55$ & $0.61 \pm 0.74$ \\
\hline $\begin{array}{c}\text { Thyroxine } \\
\mathrm{n}=5\end{array}$ & $7.88 \pm 1.02 \mid$ & $\mid 8.00 \pm 1.14$ & $\mid 2.50 \pm 1.37$ & $1.32 \pm 0.32$ & $|1.19 \pm 0.51|$ & $1.87 \pm 0.78 \mid$ & $1.13 \pm 0.59$ \\
\hline $\begin{array}{c}\text { Triiodothyronine } 2 \gamma \\
\mathbf{n}=5\end{array}$ & $7.37 \pm 0.53$ & $6.24 \pm 1.73$ & $1.75 \pm 0.49$ & $\begin{array}{l}-0.19 \pm \\
0.46\end{array}$ & $0.12 \pm 0.53$ & $0.14 \pm 0.97$ & $0.40 \pm 0.24$ \\
\hline
\end{tabular}

場合はFig.30の如くで全例において対照（Fig.27）と較べ明らかに眼突の程度が軽かつた。

実験 7 乾燥甲状腺末， $T_{4}$ 或いは $T_{3}$ ट Pretiron の同時投与 (Fig. 31，32，33，34，Table 14)

甲状腺ホルモン前処置後 Pretiron を投与した場合は先の実験の如くで， $\mathrm{T}_{3}$ で抑制効果がみられたため 本実験では甲状腺ホルモンと Pretiron を同時投与した，成績はFig.32，33，34の如く Thyradine 20mg， $\mathrm{T}_{4} 50 \gamma, \mathrm{T}_{3} 2 \gamma$ を Pretiron $5 \mathrm{JSU}$ と同時投与しても，その眼突反応は Pretiron と生食投与の対照（Fig. 31) と全く差はみられなかつた。

$$
\text { IV 考 按 }
$$

1929年 Loeb and Basett ${ }^{18)}$ が下垂体前葉より TSH を分離してから 2 年後の 1931年, Schockaert ${ }^{1)}$ が若 いアヒルに牛の下垂体前葉の抽出物を注射して初めて実験的に眼突を起てしている．その後多くの学者が色

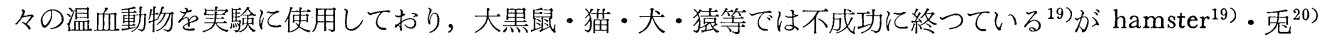
・海猉では実験的眼突に成功している。乙のうちでは海猽が一番よく使用されており多数の報告がみられ $ろ^{21 \sim 29)}$.

1945年 Albert ${ }^{2)}$ が初めて羊の脳下垂体抽出物に非常に感受性のある common Atlantic “minnow” る 第40巻 第 8 号 
つけてから，魚が広く用いられるようになり鯉 (Cyprinus carpio(16)30)，鮒 (Cyprinus auratus ${ }^{31)}$ )，金魚 (Carassius auratus var. laponicus $\left.{ }^{32} \sim 36\right)$, Salmo salar $^{37)}$, Salmo gairdneriii ${ }^{28}$, Saivelinus fontinails ${ }^{37}$, Anguille femelle ${ }^{39}$, teleost fish ${ }^{10)}$ 等を実験に用いた報告がみられる。 common Atlantic “minnow”を用 いての眼突反応はその後多くの研究者 599 911)40 43)により観察されているが，ての魚は我が国では入手し難い 為著者は入手，飼育容易な又廉価な市販の金魚の一品種である和金を実験動物に用いた，上述の如く検定動 物に金魚を用いた報告はあるが詳細な記述にとぼしく，従つて著者は一年間金魚を観察すると同時に基礎的 な実験も合わせ行なつた。

水温 $24^{\circ} \mathrm{C}$ で金魚を自然放置した時 ICD 亿著しい日内変動はなく，鰖切断や注射針穿刺の機械的刺㦸も特 に ICD 亿影響を与えなかつたてとから，更に又生理的食塩水注射の場合に示す ICD の $95 \%$ 信頼区間の変 化とから著者は $5 \%$ 迄の ICD 变化は自然変動とみなし，5\%以上示した場合を初めて眼突ありとする基準 をもうけた。

TSH 製剤である Pretiron を投与した場合，和金では投与 4 ～７時間目で ICD が最高変化を示したが， Fundulus に羊の pituitary extract を注射した Albert, ${ }^{2)}$ strandard pituitary extract を注射した Dobyns and Wilson ${ }^{15)}$ 等は24時間目，又鯉に reference standard を注射した Der Kinderen et al ${ }^{16)} は 24 〜 48$ 時間 目に ICD が最高値を示したと報告している。

著者の用いた大きさの金魚即ち $7 \mathrm{~cm} ， 4 \mathrm{gm}$ 前後では24時間後には眼突がすでに消失する傾向にあり注意 しなければならない，てのように 5 時間前後で ICD が最高変化を示したという報告はなく，著者は海犋や 他の温血動物に比し極めて少量の試料でしかも短時間で眼突効果を判定出来るという利点から，和金が最も 優れた検定動物であると考光る，ての最高変化佂要する時間の違いは Fundulus と金魚という種差或いは 魚の大きさの差が第一に考元られるが，一方試料の純度により吸収に差が出るととも考えられる．著者は column で分離した Fraction でてのような 1 時間々隔での計測は行なわなかつたが更に敏感な反応を示す ことが予想される.

鯉を用いた Der Kinderen et $\mathrm{al}^{16)}$ はてれら動物に季節的変動なく一年中使用出来ると報告しているが， 著者の経験では年中一定した大きさの鯉を得ることは困難と思われる．Fundulus は Johnson ${ }^{44)}$ が述べてい るように sexual activity の間が特に反応がよく，一方又 Dobyns et $\mathrm{al}^{45)}$ は冬が一層反応性にとんでい ると述べている，著者は同時に入手した金魚で 6 日後水温が $25^{\circ} \mathrm{C}$ から $30^{\circ} \mathrm{C}$ に上昇した時，同じ $\mathrm{TSH}$ 製剤 でも眼突反応が $9.07 \%$ から $3.94 \%$ と低くなり，水温が $30{ }^{\circ} \mathrm{C}$ を越す夏は反応が弱くなり和金に季節的変動のあ るとと知つた，又 Day ${ }^{11)}$ は金魚が TSH 製剤の注射で眼突反応を示さず，てのととは反応性にとむ Fundulus と比較して種の相違によるのだと説明しているが，金魯が眼乫反応に敏感なととは著者の実験でも明 らかである。一方 TSH 製剤でも余り眼突の認められない金魚もあり，Dobyns and Wilson ${ }^{15)}$ の云う如く 平均値で表現することには問題があるようで，著者は ICD 変化を個々に図示して眼突効果を判定した。 て のような反応の差は個体差のみならず植村 ${ }^{46)}$ 等が報告しているように，雄群に反応が強いという性差による のかもしれない.

下垂体前葉抽出物にて眼突効果を調べた報告は前述の如く Schockaert ${ }^{1)}$ 以来諸家の報告があるが，TSH 製剤にて眼突効果のあることを初めて報告したのは1954年 Pickford7) で Fundulus に Armour の Thyrotropin を注射して眼突を起ししている。最近では1960年 Der Kinderen et $\mathrm{al}^{16)}$ が市販の TSH 製剂(オ ランダ Organon 社の Reference Standard) を用いて鯉とおける著明な眼突を報告しており, 日本では永 田 ${ }^{33}$ が金魚を使つて Pretiron $10 \mathrm{JSU} / 0.5 \mathrm{ml}$, 或いは $15 \mathrm{JSU} / 0.5 \mathrm{ml}$ で何れも眼突の生ずることを観察して いる. 著者はPretiron での眼突効果がすでに消退した 5 日目に再度 Pretiron を投与して眼突を起てして おり，金魚の眼乫反応が Pretiron によつて惹起されるととを確認した，又 Pretiron 投与量を1.25，2.5, $5.0,10.0,20.0 \mathrm{JSU}$ と增やした場合その眼突度との間には，投与 5 時間目では $1.25 と 10.0 \mathrm{JSU}$ の間で直 線的な増加のあるととが認められた。 このととは Der Kinderen et al ${ }^{16)}$ が Reference Standard(Organon)

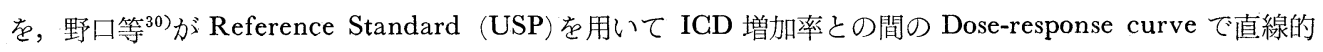


的な関係を得ているのとよく一致している。

てのように TSH 製剤に眼突を起こさせる因子のあることは明らかであるが，TSH そのものに眼突作用 がある報告としては Asboe-Hansen et $\mathrm{al}^{48)}$ が悪性眼突患者の血清 $\mathrm{TSH}$ 量が10例中 9 例に上昇していたて とから, 又 Asboe-Hansen et $\mathrm{al}^{49)}$ はその患者の眼䆚内における組織学的変化と血清 TSH 量が平行してい たととから，Pickford ${ }^{47)}$ は Thyrotropin における甲状腺刺㦸作用と眼突作用との間に量的な平行関係のあ るととから, Sonenberg and Money ${ }^{50)}$, Lamberg et $\mathrm{al}^{51)}$, Wegelius et al ${ }^{52)}$ 等は ${ }^{35} \mathrm{~S}-\mathrm{TSH}$ が眼窩内組織に 選択的に集まるととから, 又 Albeaux-Fernet et $\mathrm{al}^{53)}$ は重症進行性眼突患者の下垂体に TSH 分泌圥進像 を認めたてとから，或いは又 Purves and Griesbach ${ }^{54)}$ は眼突と血清 TSH との間には著明な相関があると しており，眼突反応は TSH それ自身による作用であるとしており Smelser ${ }^{24)}$ ，Paulson ${ }^{25)}$ ， Pochin ${ }^{29)}$ も同様 の立場をとつている.

これに反して Simkin and Starr ${ }^{55)}$ は人に TSH 製剂を投与したにも拘らず眼突は起てらなかつたと報告 しており，Dobyns ${ }^{56)}$ は各種の下垂体エキスが同じ TSH 効果を示すに拘らず眼突効果において異なること を確認している. 更に1953年 Dodyns and Steelman ${ }^{3)}$ は下垂体前葉抽出物に $8 \%$ 三塩化酢酸を加え，生じた 沈澱物から TSH 作用はないが眼乫効果の著明な物質を分離してれを Exophthalmos Producing Substance と呼んだ. 彼より先1949年 Jefferies ${ }^{4)}$ は下垂体抽出物を iodination するととにより，TSH 作用はなくな るが眼突作用の残こるととを報告しており, 更に1958年 Brunish ${ }^{5)}$ は牛下垂体前葉からの抽出物を, 又 TSH 製剤の Armour's Thytropar をそれぞれ pepsin で消化するととにより，TSH 活性は低くなるが眼突効 果は殆んど不変であるととを，1959年 Bates et al ${ }^{57)}$ は Furth ${ }^{58)}$ が記載した mouse における移植可能で, TSH を産生する下垂体腫瘍に眼突作用のないととを発表しており，乙の外 Der Kinderen et al ${ }^{16)}$ は眼突患 者血清と匹敵する鯉眼突効果を下垂体前葉製剤で期待する場合，その中にある TSH 濃度は患者血清中で予 想されるよりも遙かに高かくなければ眼突を起とさないととから TSH と EPS は別個のものであるてとを 推測している. Gilliland and Strudwick ${ }^{59)}$ は眼突のみられない粘液水腫に TSH が多く, 又重篤な眼症状が あり乍ら TSH 量の上昇の認められなかつた症例を報告しており, 更に又血中 TSH 量と眼症状が必ずし

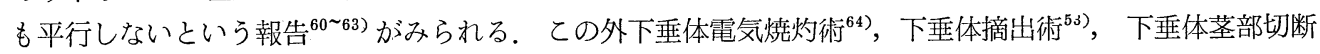
術 $^{65)}$, 間脳下垂体レントゲン照射 ${ }^{66}$ (68)等の治療により眼突が軽快するという臨床的事実から, EPS が間脳 下垂体系に関係があると思われる。

このように甲状腺中毒症患者の血中には TSH が増えているという報告と，増えていないという報告が あり長らく論争が続いてきたのであるが，乙の原因には TSH の抽出法，検定法の不完全，不統一という 技術的な面と, Adams ${ }^{69}$ や Mc Kenzie ${ }^{70)}$ のいう所謂 abnormal TSH 或いは LATS (Long-Acting Thyroid Stimulator) が，甲状腺中毒症患者の或る者に増加しているという病態生理学的な面に依存してい るのではないかと思われる。

1958年 Adams ${ }^{69}$ は abnormal TSH が Dobyns のいう EPS と一致すると説いたが，1961年 Mc Kenzie 71)の論文では LATS が現在甲状腺中毒症と眼突の両方を訴えたものでは89\%に認められ，過去に中毒症が あるか現在眼突のない場合は $40 \%$, 又既往症及び現症に甲状腺中毒症と眼突のないものでは $4 \%$ 認めら れないと報告している.

このように眼突と LATS とは相関があるようにも思われるが，若し EPS と LATS が同じものであれ ば LATS が下垂体の手術をうけた人間に証明されたり ${ }^{71) \tau 2)}$, 又 TSH が Bates の percolation $\operatorname{method}^{73)}$ により下垂体から抽出されるに反し，LATS は抽出されないことから LATS は下垂体で産出されるので はないらしい. 従つて下垂体抽出物で眼突が起てる実験的事実から, 並びに最近の我々の研究 data ${ }^{74)}$ から も EPS と LATS は同一物ということは否定され得る. 故に既述のととから EPS は下垂体に存在するが $\mathrm{TSH}$ と別個のものであるととが推測される。著者も上述の文献的考察から TSH と EPS は異なつた物質 であるという観点から出発して，イオン交換セルローズを用いて両者の分離を試みてみた。

cellulose column chromatography は ion exchange chromatography の一つであり，その溶出が種々の

$$
\text { 第 } 40 \text { 巻 第 } 8 \text { 号 }
$$


因子で多大に影響されることはよく知られている，pH は殊に吸着や溶離に 鋭敏に 左右するので， elute buffer の $\mathrm{pH}$ 調整には特に留意した。温度の変化により $\mathrm{pH}$ が変化するととから著者は大体 $4{ }^{\circ} \mathrm{C}$ の状態 で処定の $\mathrm{pH}$ に調整した. Cellulose column を作製してから試料を charge する前に，充分 column を bufferize して pH を合わすと同時に cellulose が均一に充填されるようにした，又との cellulose のイオ ン結合の capacity を決めるため， CM-G の場合 Pretiron 375, 250, 125JSU をそれぞれ展開し，その展 開曲線から 250JSU 以下なら妥当であるととを知り以下の実験では Pretiron 250JSU を charge するてと にした，DEAE-C の場合も同様の検討を加え 375JSU を charge した.

Bates et $\mathrm{al}^{75}$ は牛の下垂体の crude TSH を CM-G にて pH 6.25, 0.01M Sodium phosphate; 1.0M $\mathrm{NaCl}$ の順で elute し後者の Fraction 中にかなり精製された TSH を得たが，乙の際 EPS 活性は前者の Fraction に強かつたと報じている。が彼等は TSH と EPS の分離に関する実験結果 の詳しい記載はして いない。野口等 ${ }^{30}$ は USP Reference Standard を $\mathrm{pH}$ 6.0,0.01M Sodium phosphate; 1.0M NaCl で展 開した場合 TSH 活性は後者に強く，EPS 活性の方は両者に分散して現われたがやや前者に強かつたと報 じている.

著者は Pretiron を $\mathrm{pH}$ 6.3, 0.01M Sodium phosphate；1.0M NaCl の順で elute したが， EPS と TSH は Column に吸着されて Fraction A には現われず，Fraction B に溶出されてき両者を分離出来なかつ た. そてで共に溶出されてきた Fraction B の部分を， NaCl の mol 濃度を0から $1.0 \mathrm{M}$ 迄直線的に增加 させ展開した場合，両者の溶出される態度に差はないかと考光 linear gradient elution を行なつた。然 しFig.14の如く Fraction E の部分, 即ち $\mathrm{NaCl}$ の濃度にして 0.23 0.36M の間で両者が溶出されてき 同じく分離出来なかつた。

次に著者は DEAE-C の場合 $\mathrm{pH} 9.5,0.005 \mathrm{M}$ sodium glycinate; $\mathrm{pH} 9.5,0.1 \mathrm{M}$ sodium glycinate; $0.2 \mathrm{M} \mathrm{NaH}_{2} \mathrm{PO}_{4} ; 1.0 \mathrm{M} \mathrm{NaCl} の 4$ 種の elute buffer を使用したが， TSH も EPS も 0.005M sodium glycinate の展開の時は column に吸着されており, TSH は $0.2 \mathrm{M} \mathrm{NaH}_{2} \mathrm{PO}_{4}$ の所で大半が溶出されてき た. EPS 活性は Fraction G,H,I で共に同程度に認められた。 てのように Fraction H に TSH 活性が極 めて強かつたにも拘らず眼笑効果の著明に認められなかつたてと, 又 TSH 活性の低い又全くない Fraction G, I に眼突効果の認められたてとから，眼突反応はTSH そのものによるのではなくて他の因子，恐らく EPS によることを確認するととが出来た.

1957年 Langford ${ }^{9}$ は乾燥甲状腺末 $0.6 \mathrm{mg}$ ，Triiodothyronine $\left(\mathrm{T}_{3}\right)$ の $0.1 ， 0.2 ， 0,5,1,0 \gamma$ をそれぞれ Fundulus heteroclitus に投与して眼突の起きたてとを報告し，翌1958年 Matty et al ${ }^{10)}$ は Sparisoma squalidum, Scarus croicensis, Bathystoma aurolineatum なる 3 種の teleost fish $に \mathrm{~T}_{4} 10,500 \gamma, \mathrm{T}_{3} 5 \gamma$ を投与して著明な眼突を認めている。 Pickford and $\mathrm{Atz}^{40)}$ は乾燥甲状腺末或いは $\mathrm{T}_{4}$ の長期経口投与で，数 種の魚に眼突を起てしたという報告を引用しており，Harms ${ }^{76)}$ は長期 $T_{4}$ 注射での眼突を，又 La Roche and Le Blond ${ }^{37)}$ は $\mathrm{T}_{4}$ 並びそ乾燥甲状腺末を Salmo salar や，Salvelinus fontinalis に投与しての ICD の增加を報告している。乙れに反し Albert ${ }^{2)}$ は $\mathrm{T}_{4}$ が，Day ${ }^{11)}$ は $\mathrm{T}_{3} \mathrm{l}_{\gamma}$ が Fundulus に眼突を起てさぬ こと，1962年 Dobyns et al ${ }^{12)}$ も又 $\mathrm{T}_{3} 1.0,2.5,2.75 \gamma$ で眼突の起とらぬととを認めている. Dobyns et al ${ }^{12)}$ は Langford9) の用いた $\mathrm{T}_{3}$ は錠剤であるため，その賦形薬に眼突作用があるのだと推定しており，又彼 は結晶 $T_{3}$, 錠剂 $T_{3}$ でも意味ある眼突を起てさなかつたてとを確認している。古くは Kunde ${ }^{20)}$ ， Smith ${ }^{77)}$ は $\mathrm{T}_{4}$ 或いは乾燥甲状腺末で哺乳動物に眼突が起きたとしているが，Carlson et $\mathrm{al}^{79}{ }^{79}$ ，Pochin ${ }^{79)}$ は同じ方法で 眼突を認めておらず，又甲状腺機能進症における甲状腺の外科的切除や，抗甲状腺剤の治療においてみら れる眼突の元進 ${ }^{80811}$, 或いは眼突に対する ${ }^{131} \mathrm{I}$ の治療効果 ${ }^{82}$ 85), 或いは眼突に対して $\mathrm{T}_{4}, \mathrm{~T}_{3}$ が効くと

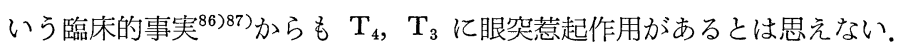

てのように甲状腺ホルモンの眼突作用については区々の成績が得られているので著者は乾燥甲状腺末， $\mathrm{T}_{4}, \mathrm{~T}_{3}$ の眼突効果を少量の場合と大量の場合で検討を加えたが， Thyradine $20 \mathrm{mg}$ 投与では 4 日目にか なりの眼突が起こり，従つて乾燥甲状腺末を眼突患者の治療に用いることは眼突を徳化させる可能性のある 
ことが考えられる。事実 $\mathrm{Brain}^{88)}$ は悪性眼突の治療に甲状腺剤は禁忌であると強調している，然し $\mathrm{T}_{4}, \mathrm{~T}_{3}$ では Langford，9) Matty et al ${ }^{10)}$ 等の説とは異なり，純粋合成品を使用したためか著明な眼突は証明されな かつた. Thyradine 大量投与での眼突の原因は不明であるか恐らく乾燥甲状腺末 を溶かすための溶媒, 或 いは又 $\mathrm{T}_{4}, \mathrm{~T}_{3}$ 以外の不明の因子による影響ではなからうかと考えられる。

次に甲状腺中毒症患者に起きる眼突の機序を解明する一端として，甲状腺ホルモンの血中増加をきたして いる時期に EPS が分泌された場合, 眼突反応は如何なる影響をうけるかを観察するために，甲状腺ホルモ ンが末梢組織で作用を発現する潜伏期間 ${ }^{17)}$ を考慮して乾燥甲状腺末， $\mathrm{T}_{4}$ では72時間後に， $\mathrm{T}_{3}$ では24時間後 に Pretiron を注射したが，乾燥甲状腺末， $\mathrm{T}_{4}$ では眼突反応は対照と余り差がなく， $\mathrm{T}_{3}$ の場合は対照に比 し全例かなり著明に抑制された。 このととは臨床的には悪性眼突に $\mathrm{T}_{3}$ が有効と述べている Williams and Bakke, $^{86)}$ Naff ziger $^{87)}$ の説を支持するものである。 $\mathrm{T}_{3}$ のこの抑制の機序は不明であるが，Asboe-Hansen ${ }^{89}$ 亿 よると TSH は球後組織の肥紏細胞の数を増加させると同時に原形質の顆粒をふやし，ての顆粒はヒアルロ ン酸と考えられとのものが親水性のため浮腫を生ずるのだと述べている．従つて球後組織の TSH に対する

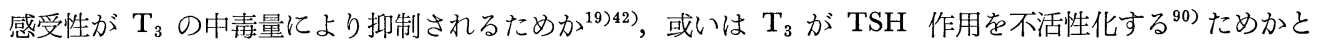
も考えられる. 故に眼突の治療には $\mathrm{T}_{3}$ と $\mathrm{T}_{4}$, Thyradine を使い分ける必要があると云える.

最後に著者は ion exchange chromatography としては GM-G と DEAE-G の二種につき検討を加えた が，一般に TSH 活性物質の分離には CM-C より DEAE-C の方が TSH の吸着力が高くて適当である ため, EPS との分離を期待したのだが両者の理化学的性状が良く似ていたため著明な分離をなし得なかつ たととは前述した．採用した ion exchange chromatography の条件は，下垂体前葉抽出物から TSH 精製分離する目的で行なつた Condliffe and Bates, ${ }^{73) 74)}$ Condliffe et al ${ }^{1)}$ の方法にのつとつたものであつて EPS の分離に最適の条件ではないかもしれない. elute buffer の種類, $\mathrm{pH}$, イオン強度, モル濃度, 溶出 速度等で試料の分離が 鋭敏に左右されることは周知の如くで，今後更にこういつた条件の検討並びに gradient elution, rechromatography, ion exchange chromatography と gel filtration の組合わせ, 又 CM-或いは DEAE-Sephadex 等で検討を加えるなら両者を分離出来る可能性が考えられる.

\section{$\mathrm{V}$ 総括及び結語}

和金の眼突検定動物としての基礎的研究と, TSH 製剤である Pretiron 中の EPS の分離, 並びに甲状 腺ホルモンが Pretiron の眼球突出反応に与える影響を検討し以下の如き成績を得た。

1) 和金の ICD は自然放置では一定した日内変動なく，䰹切断や注射針穿刺による機械的刺㦸にも影響 されず，餌を与えなくても減少しなかつた。

2 ） $0.9 \%$ 食塩水注射では最大変動は $5 \%$ 迄で, 著者は $5 \%$ 以上を眼突ありと判定した. Pretiron 注射で は 3 時間後すでに肉眼的眼突が発現し，5時間前後で ICD 増加率の peak が来た. 又 Pretiron 注射でも 水温が $30^{\circ} \mathrm{C}$ を越す夏は金魚の眼突反応が悪かつた。

3) Pretiron 注射 5 時間目では，1.25JSU から 10.0JSU の間で ICD の percent increase は直線的であ り，10時間目では 1.25JSU から 5.0JSU の間でほぼ直線的に増加した.

4) Pretiron を CM-G で stepwise に column chromatography せる場合，第 II 分画に TSH 活性も EPS 活性も認められ，gradient elution せる場合は第II分画後半に同じく TSH 活性も EPS 活性も認め られ両者を分離出来なかつた。

5) Pretiron を DEAE-C で column chromatography せる場合, TSH 活性は第吕分画に強かつたが EPS 活性は第II， III，IV分画に平等に分散して現われたてとから，TSH と EPS は別個のものであること を知つた.

6) Thyradine 大量投与では 4 日目にかなりの眼突が起てり， $T_{3}$ では著明な眼突作用はみられなかつた. 又 $\mathrm{T}_{4}$ では対照と差がなかつた。

7) Thyradine， $T_{4}$ 或いは $T_{3}$ を投与してから Pretiron を注射した場合， $T_{3}$ は Pretiron の眼突反応を 第 40 巻 第 8 号 
かなり著明に抑制したが，他の二者では対照と差がなかつた。

以上のととから眼突活性の検定に金魚の有用なとと，EPS は TSH と非常に類似しているが別個のもの であるとと，乾燥甲状腺末は眼突を増悪させる可能性があるが， $T_{3}$ は眼突の治燎に応用出来ることの根拠 を得た.

尚本論文の要旨は第34回（昭和36年 4 月），第35回（昭和37年 4 月），第36回（昭和38年 4 月）日本内分泌 学会総会, 又第76回大阪市医学会（昭和39年 2 月）に扔いて発表した.

稿を終るにあたり，終始御賏切な御指導並びに御校閲を戴いた塩田教授に深く感謝し，併せて種々御助言 及び御協力下さいました藤田栄一博士, 蔵田典光博士, 大楠隆略学士に深謝すると共に, 実験にあたり種々 御便宜下さつた本学生化学教室（主任大谷象平教授）の奥田清講師並びそ諸先生方に御礼申上げます。

\section{文献}

1) SGHOCKAERT, J.A. : Proc. Soc. Exper. Biol. and Med., 29 : 306, (1931).

2) ALBERT,

A. : Endocrinology, 37 : 389, (1945). $\quad 3$ 3) DOBYNS, B.M. and STEELMAN, S.L. : Endocrinology, $52: 705$, (1953). $\quad$ 4) JEFFERIES, W.M. : J. Clin. Endocrinol., $9: 927$, (1949).

BRUNISH, R. : Endocrinology, $62: 437$, (1958). $\quad$ 6) CONDLIFFE, P.G. and BATES, R.W. : J. Biol. Chem., 223 : 843, (1956). $\quad$ 7) CONDLIFFE, P.G. and BATES, R.W. : Arch. Biochem. Biophys., 68 : 229, (1957) $\quad$ 8) CONDLIFFE, P.G., BATES, R.W. and FRAPS, R.M. : Biochim. Biophys. Acta, $34: 430$, (1959). 9) LANGFORD, H.G. : Endocrinology, $60: 390$, (1957). 10) MATTY, A.J., MENZEL, D. and BARDACH, J.E. : J. Endocr., 19 : 314, (1958).

DAY, R.M. : Arch. Ophth., 64 : 324, (1960).

SANDERS, M.A. : Endocrinology, 70 : 864, (1962).

TISELIUS, A. : Acta Chem. Scand., $6: 826$, (1952).

12) DOBYNS, B.M., WRIGHT, A. and 13) ALM, R.S., WILLIAMS R.J.P. and

14）小倉一: 日内科誌, $48: 1045 ;(1959)$. 15) DOBYNS, B.M. and WILSON, L.A. : J. Clin. Endocrinol. and Metab., $14: 1393$, (1954). 16) DER KINDEREN, P.J., HOUTSTRAlAnZ, M. and SGhWARZ, F. : J. Clin. Endocrinol. and Metab., $20: 712,(1960)$ 17) PITT-RIVERS, R. and TATA, J.R. : The Thyroid Hormones, (1959), 90, Pergamon Press, London, New York, Paris and LosAngeles.

18) LOEB, L. and BASETT, R.B. : Proc. Soc. Exper. Biol. and Med., 26 : 860, (1929).

19) SMELSER, G.K. :

Am. J. Ophth., 54 : 928, (1962). $\quad$ 20) KUNDE, M.M. : Amer. J. Physiol., 82 : 195, (1927).

21) LOEB, L. and FRIEDMAN, H. : Proc. Soc. Exper. Biol. and Med., 29 : 648, (1932).

22) MARINE, D. and ROSEN, S.H. : Proc. Soc. Exper. Biol. and Med., 30 : 901, (1933).

23) FRIEDGOOD, H.B. : Bull. Johns Hopkins Hosp., 54 : 48, (1934). 24) SMELSER, G.K. : Proc. Soc. Exper. Biol. and Med., 35 : 128, (1936). 25) PAULSON, D.L. : Proc. Soc. Exper. Biol. and Med., 36 : 604, (1937). 26) AIRD, R.B. : Arch. Ophth., $24: 1167$, (1940).

27) AIRD, R.B. : Ann. Inter. Med., $15: 564$, (1941). $\quad 28)$ DOBYNS, B.M. : Surg. Gynec. and Obst., 82 : 290, (1946). 29) POCHIN, E.E. : Ciba Fouud. Coll. Endocrinol., $4: 316$, (1952). 30）野口秋人, 佐藤誠也, 山崎鋭一 : ホルモンと臨床, $10: 29,(1962) . \quad 31)$ 加嶋政昭, 佐藤 智, 田中勝治, 青池 明: 日内科誌, $44: 324,(1955)$. 32) CANADELL, J.M. and BARRAQUE R, J. : Ann. Endocrinol., 17 : 369，(1956). 33$)$ 永田 格：日内分泌誌，35：1386，(1960). 34) DAY, R.M. and NELSON, R. : Am. J. Opth., 50 : 1193, (1960). 35) MC GILL, D.A. : Quart. J. Med. (New Serirs), XXIX : 423, (1960). 36 ) 植村恭夫 : 臨眼, $15: 76$, , (1961). 37) LA ROCHE, G. and LEBLOND. C.P. : Endocrinology, $51: 524$, (1951).

ROBERTSOM, O.H. : Trans. Ass. Amer. Physicians, $68: 33$, (1955). $\quad 39$ ) GINESTE, P.J. : 
G.R. Soc. Biol. (Par)., 149 : 551, (1955). : New York Zoological Society, (1957). 文献11) より引用. M.A., ROSENBAUM, H. and BEGKER, B. : Am. J. Ophthal., 45 : 930, (1958). DELL, J.M. and BARRAQUER, J. : Endocrinology, 64 : 1017, (1959). BRALEY, A.E. and HAMILTON, H.E. : Amer. J. Ophthal., 50 : 783, (1960).
40) PICKFORD, G.E. and ATZ, J.W. : New York 41) POLLAGK, I., CONSTANT,

43) SCHULTZ, R.O., 44) JOHNSON, L.V. : American Ophthalmological Society, White Sulphur Springs., W. Va., May 28, (1958). 文献11) より引用. 45 DOBYNS, B.M., WRIGHT A. and WILSON, L. : J. Clin. Endocrinol. and Metab., $21: 648$, (1961). 46) 植村恭夫, 須賀純之助 : 日眼, $65: 1851 ，(1961)$ 47) PICKFORD, G.E. : Endocrinology, $55: 589$, (1954). 48) ASBOE-HANSEN, G., IVERSEN, K. and WICHMAN, R. : Acta Endocrinol., $11: 376$, (1952). 49) ASBOE-HANSEN, G., QUAADE, F. and WICHMAN, R. : Acta Endocrinol., 18 : 557, (1955).

50) SONENBERG, M. and MONEY, W.L. : Recent Progress in Hormone Research, 11:43, (1955). LAMBERG, B.-A., WEGEliUS, O. and HAR JANNE, A. : Acta Endocrinol., 22 : 407, (1956). 52) WEGELIUS, O., NEUMAN, J. and BRUNISH, R. : Acta Endocrinol., 30 : 53, (1956). 53) ALBEAUX-FERnET, M., GUIOT, A., BRAUN, S. and ROMANI, J.D. : J. Glin. Endocrinol. and Metab., 15 : 1239, (1955). $\quad$ 54) PURVES, H.D. and GRIESBACH, W.E. : Brit. J. Exper. Path., $30: 23$, (1949). $\quad 55)$ SIMKIN, B. and STARR, P. : Proc. Soc. Exper. Biol. and Med., 84 : 99 , (1953). 56) DOBYNS, B.M. : Surg. Gynec. and Obst., $82: 290$, (1946, a). $\quad$ 57) BATES, R.W., ALBERT, A. and CONDLIFFE, P.G. : Endocrinology, $65: 860$, (1959). 58) FURTH, J. : Recent Progress in Hormone Research, $11: 221$, (1955). 59) GILLILAND, I.C. and STRUDWIGK, J.I. : Brit. Med. J., $1: 378$, (1956). $\quad 60)$ D'ANGELO, S.A., PASCHKIS, K.E., GORDON, A.S. and CANTAROW, A. : J. Glin. Endocrinol., $11: 1237$, (1951). 61) BLOCHMICHEL, H. and HENRY, R. : Ann. Endocrinol., $16: 268$, (1955). $\quad 62$ ) 小倉 一, 佐古田雅弘 : 日内分泌誌，34:274，(1958). 63) 永田 格：日内分泌誌，35:1285，(1960). 64) RASMUSSEN, A.T. and GARDER, W.J. : Endocrinology, $27: 219$, (1940). 65) Mc CULLAPH, E.P., GLAMEN, M. and GARDNER, W.J. : J. Clin. Endocrinol. and Metab., $17: 1277$, (1957). 66) LAMBERG, B.-A. : Acta Med. Scandinav., $156: 361$, (1957). 67) LAMBERG, B.-A. : Acta Med. Scandinav., $156: 377$, (1957). 68) LAMBERG, B.-A. : Acta Med. Scandinav., 156 : 391, (1957). $\quad$ 69) ADAMS, D.D. : J. Clin. Endocrinol. and Metab., $18: 699$, (1958). 70) Mc KENZIE, J.M. : Endocrinology, $62: 865$, (1958). $\quad$ 71) Mc KENZIE, J.M. : J. Clin. Endocrinol. and Metab., $21: 635$, (1961).

72) FURTH, E.D., BECKER, D.V., RAY, B.S. and KANE, J.W. : J. Clin. Endocrinol. and Metab., $22: 518$, (1962).

73) BATES, R.W., GARRISON, M.M. and HOWARD, T.B. : Endocrinology, 65 : 7, (1959).

74) 塩田憲三, 蔵田典光,

鳥辺博正，大楠隆昭 : 第36回日本内分泌学会総会，(1963).

P.G. : Recent Progress in Hormone Research, 16 : 309, (1960).

Zool., $146: 417$, (1935).
77) SMITH, J.H. : Arch. Int. Pharmacodyn., 59 : 217, (1938). 78) CARLSON, A.J., ROOKS, J.R. and Mc KIE, J.F. : Amer. J. Physiol., 30 : 129, (1912). 79) POCHIN, E.E. : Clin. Sci., 5 : 75, (1944). $\quad$ 80) DOBYNS, B.M. : Surg. Gynec. and Obst., $80: 526,(1045)$. $\quad$ 81) HAYLES, A,B., KENNEDY, R.L.L., BEAHRS, O.H. and WOOLNER, L.B. : J. Clin. Endocrinol. and Metab., $19: 138$, (1959). $\quad$ 82) HAINES, S.F., KEATING, F.R., POWER, M.H., WILLIAMS, M.M.D. and KELSEY, M.P. : J. Glinol. Endocrinol., 8 : 813, (1948). 83) CLARK, D.E. and RULE, J.H. : J.A.M.A., $139: 995$, (1955). $\quad$ 84) CHAPMAN, E.M. and MALOOF, F. : Medicine, $34: 261$, (1955). 85) 藤田栄一：第 2 回甲腺同好会研究会, (1959). 
86) WILlIAMS, R.H. : Textbook of Endocrinology, 3rd. Ed. (1962), 150, W.B. Saunders Co., Philadelphia and London. $\quad$ 87) WERNER, S.G. and NAFFZIGER, H.C. : The Thyroid, 2nd. Ed. (1962), 536, Hoeber Medical Book Harper and Row, New York.

88) BRAIN, R. :

Lancet, 1 : 109, (1959).

89) ASBOE-HANSEN, G. : Am. J. Med., 26 : 470, (1959).

90)

DOBYNS, B.M. and RAWSON, R.W. : Endocrinology, 49 : 15, (1951). 